\title{
Hungary: Selected Issues
}

This Selected Issues paper for Hungary was prepared by a staff team of the International Monetary Fund as background documentation for the periodic consultation with the member country. It is based on the information available at the time it was completed on May 24, 2005. The views expressed in this document are those of the staff team and do not necessarily reflect the views of the government of Hungary or the Executive Board of the IMF.

The policy of publication of staff reports and other documents by the IMF allows for the deletion of market-sensitive information.

To assist the IMF in evaluating the publication policy, reader comments are invited and may be sent by e-mail to publicationpolicy@imf.org.

Copies of this report are available to the public from

International Monetary Fund $\bullet$ Publication Services

700 19th Street, N.W. • Washington, D.C. 20431

Telephone: (202) 6237430 • Telefax: (202) 6237201

E-mail: publications@imf.org • Internet: http://www.imf.org

Price: $\$ 15.00$ a copy

\section{International Monetary Fund Washington, D.C.}





\section{INTERNATIONAL MONETRY FUND}

HUNGARY

\section{Selected Issues}

Prepared by Abdul Abiad, Daniel Leigh, and Stefania Fabrizio (all EUR)

Approved by European Department

May 24, 2005

Contents

I. Growth and Current Account Performance: Results From a

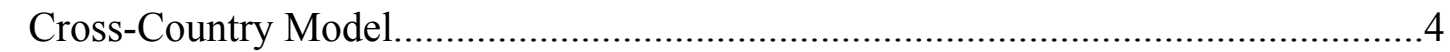

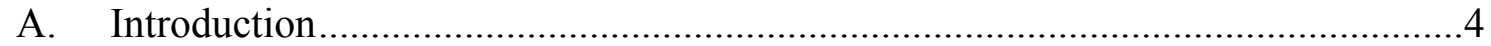

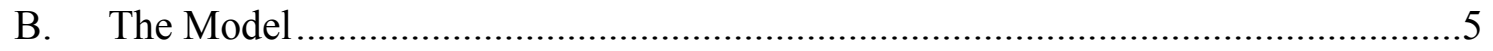

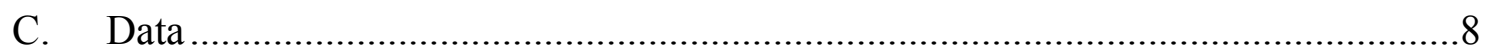

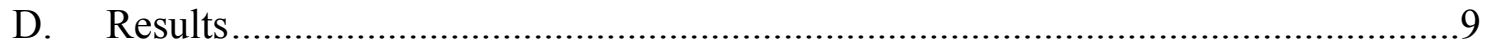

E. Conclusions ...................................................................................................

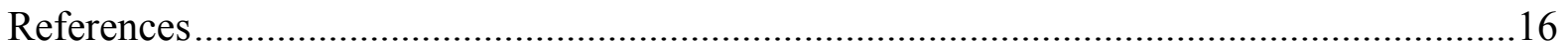

Figures

1. \& 2. Current Account Balances and GDP Growth in the EU ..........................................5

3. Absolute Convergence in Europe, 1975-2004 ……..............................................10

4. Estimates of the Speed-of-Convergence Parameter, 1975-2004 ..............................11

5. Impact of Income Per Capita on Current Account, 1975-2004................................11

6. Growth and Current Account Predictions, 1997-2004 ..........................................14

7. Lithuania: Growth and Current Account Predictions, 1996-2004 ………...............14

8. France: Growth and Current Account Predictions, 1985-2004 ………...................15

Tables

1. Estimates of Current Account Effect on Growth ......................................................12

2. $\quad$ Estimated Convergence Half and Three-Quarter Lives (In years) ...........................13

II. Fiscal Commitment: The Role of Budget Institutions ................................................17

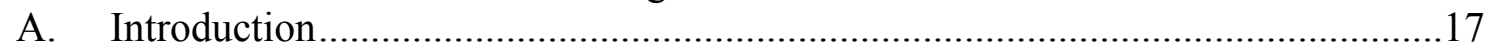

B. Budget Institutions and Their Relevance for Fiscal Performance .........................19

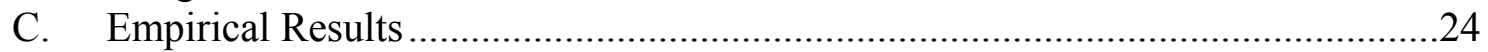

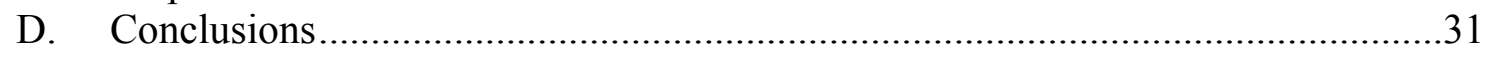

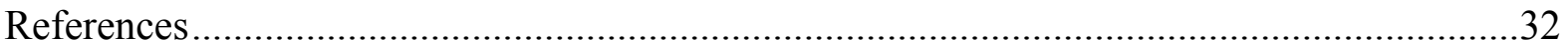




\section{Box}

1. Methodology for Dealing with Time-Invariant Political Structure Variables

Figures

1. Fiscal Deficit Performance and Targets, 2002-08 ................................................18

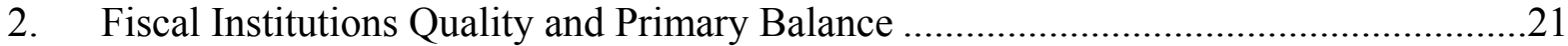

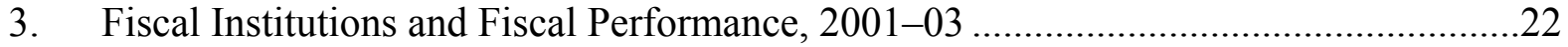

4. Budget Institutions and Fiscal Performance, 1997-2003 ..........................................23

5. Primary Balance and Fitted Values, 1997-2003 ....................................................29

Tables

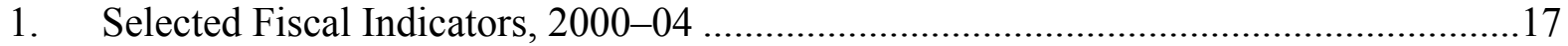

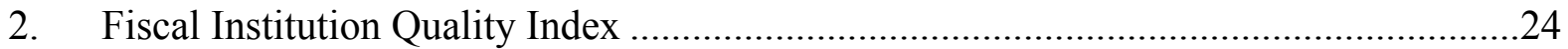

3. Budgetary Institutions and Fiscal Performance: Evidence from

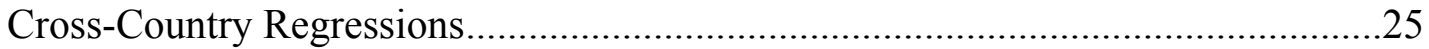

4. Budgetary Institutions and Fiscal Performance: Evidence from Panel Data Regression (Fixed Effects) ....................................................................25

5. Budgetary Institutions and Fiscal Performance: Evidence from

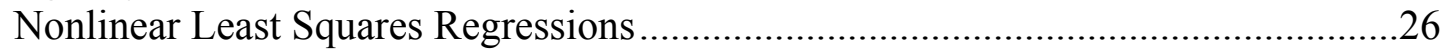

6. Budgetary Institutions (Three Phases) and Fiscal Performance: Evidence From Panel Data Regressions (Fixed Effects) ...................................................28

7. Budgetary Institutions (Three Phases) and Fiscal Performance: Evidence For Nonlinear Least Squares Regressions ........................................................28

8. Budgetary Institutions and Fiscal Performance: Evidence From Panel Data Regressions (Seemingly Unrelated Regressions Estimates)...........30

Appendix I

Construction of the Fiscal Institutions Index

Tables

1. Construction of the Index: Fiscal Institutions and Their Index Parameters...................37

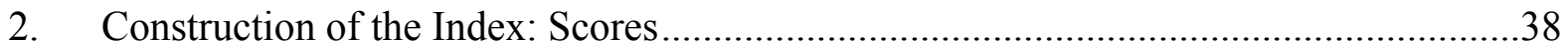

Appendix II

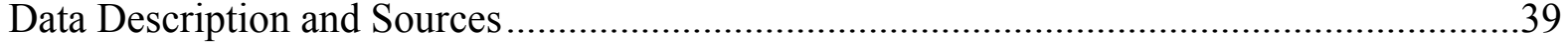

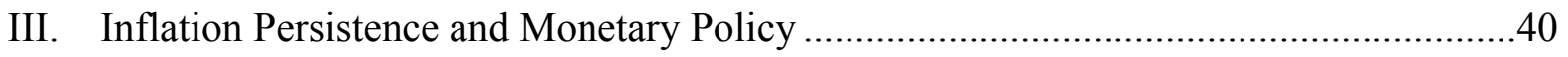

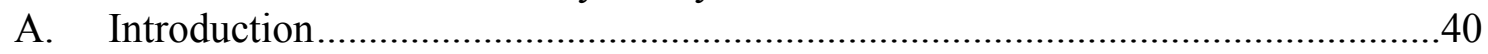

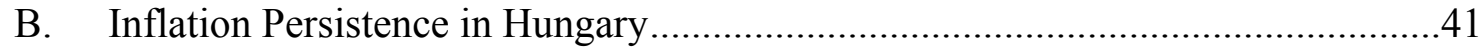

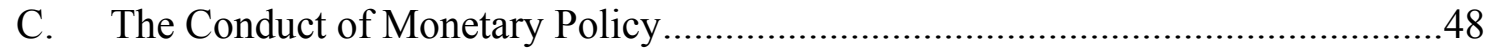

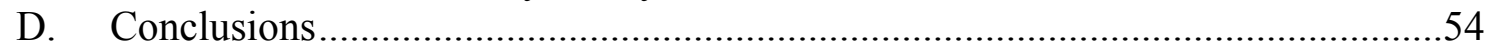

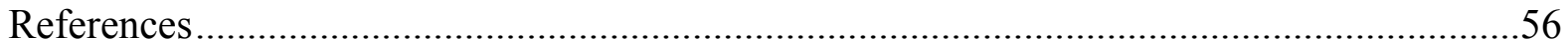


Figures

1. Inflation in Hungary and Selected CECs, 1997-2005 ...........................................40

2. Inflation Persistence in Hungary, Poland, and the Czech Republic, 1999-2005 ..........43

3. Current Inflation and Forecasts Made One Year Earlier, 1997-2005 ..........................45

4. Realized Versus Target Inflation, 2001-06 ..........................................................49

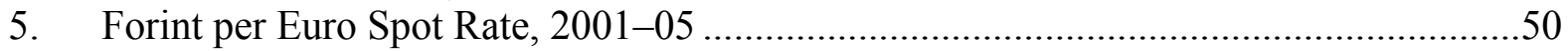

6. Interest Rate, Expected Inflation Gap, and Exchange

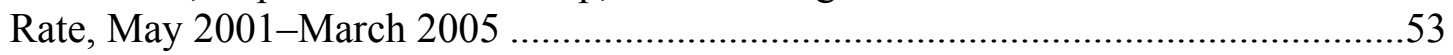

7. Counterfactual: Interest Rate Based on IT Model, May 2001-March 2005.................54

\section{Tables}

1. Estimates of Forward- Versus Backward-Looking Behavior ....................................46

2. Estimates of Speed of Updating of Household Expectations ......................................48

3. Estimates of the MNB Monetary Policy Reaction................................................53 


\title{
I. Growth And Current Account Performance:
}

\author{
Results From a Cross-COUNTRY MOdel ${ }^{1}$
}

\section{A. Introduction}

1. The European Union's (EU's) new member states have experienced relatively high rates of real income growth, alongside large external deficits. Hungary, for example, has experienced growth of about 4 percent and current account deficits of about 8 percent of GDP over the past five years, while the EU as a whole grew by 2 percent over the same period, running a balanced external account. A relatively high rate of real GDP growth is to be expected in the new member states as they catch up to the real income levels of western Europe. Similarly, increased investment to support this higher growth, as well as strong consumption based on expectations of higher future income, should generate large current account deficits.

2. What is needed are benchmarks against which to measure these GDP growth rates and current account deficits. Standard models of growth theory suggest that countries that are further behind should be expected to grow faster than other countries, all other things equal. Lower-income countries would also be expected to run larger current account deficits, as the investment opportunities are greater and the expected increase in future income is larger. But is there a quantitative benchmark one can establish to assess whether GDP growth and the current account deficits in these countries are where they should be, based on the predictions of a model of income catch-up and intertemporal optimization? For example, is Lithuania's current account deficit of 8.5 percent of GDP justifiable because it is enabling higher growth? Does convergence suggest a higher growth rate for Hungary than its current growth rate of 4 percent?

3. This chapter describes a simple empirical model that provides such benchmarks, and uses them to evaluate Hungary's growth and current account performance. The model, described in more detail in a forthcoming working paper, was developed to explore whether larger current account deficits allow lower-income countries of the EU to converge more quickly to the income levels of advanced EU countries. It also recognizes that, while growth can be influenced by the running of external deficits, the latter can also be influenced by growth. It does this by combining a modified neoclassical growth regression with a current account regression similar to the one used by Blanchard and Giavazzi (2002). Predictions of the model are used as benchmarks for countries' current performance.

4. The chapter has two main findings. First, the cross-country analysis suggests that, in general, larger current account deficits (capital inflows) are associated with faster income convergence. Second, the model's benchmark for Hungary suggests that its current account

\footnotetext{
${ }^{1}$ Prepared by Abdul Abiad and Daniel Leigh.
} 
deficit has been larger than would be expected based on the income convergence process. Hungary's current account deficit of 9 percent of GDP was about 2 percentage points of GDP higher than the central prediction of the model. And growth, though just within the 95 percent confidence band, was about 1 percentage point less than the central prediction.

5. The rest of the chapter proceeds as follows. Section B describes the motivation for, and specifics of, the modeling strategy. The data used in the analysis are described in Section $\mathrm{C}$, while Section D discusses the estimation results and analyses Hungary's growth and current account performance. Section E concludes.

\section{B. The Model}

\section{Stylized facts and theoretical motivation}

6. There is a clear link between growth and the current account. Scatterplots of GDP growth against the current account show that higher growth is associated with larger current account deficits, both over short one-year horizons (Figure 1) and over longer periods (Figure 2). Simple as they are, these scatterplots are already informative, as they allow us to roughly approximate the growth rates that are associated with a given level of the current account. The best-fit line suggests that an increase in the current account deficit of 2 percentage points of GDP is associated with a 1-1.4 percentage point increase in GDP growth. Deviations from the best-fit line are also informative, as they show that some countries are growing rapidly at present without incurring significant external liabilities, while others could be expected to grow faster given the level of the current account (or conversely, that they should have a smaller current account deficit given their present growth rates).

Figures 1 and 2. Current Account Balances and GDP Growth in the EU
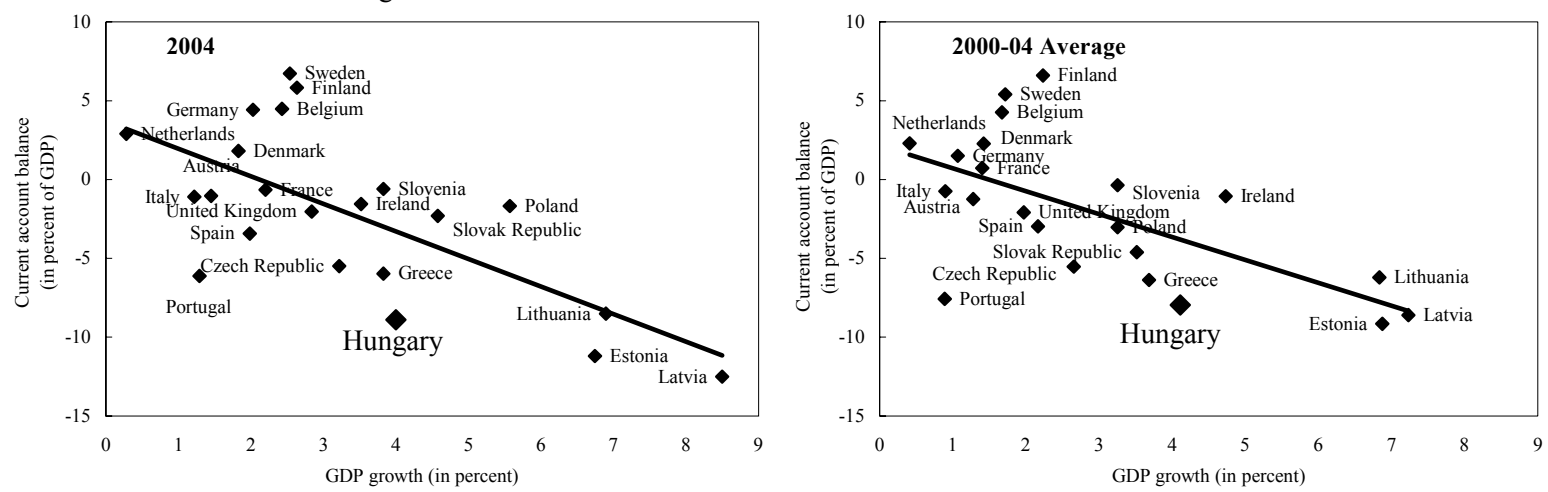

Source: IMF World Economic Outlook database.

7. Theoretical models predict that external borrowing will be driven by future growth prospects. To the extent that low per capita incomes reflect relative scarcity of capital, we should find lower levels of per capita income associated with greater external borrowing to finance high-return investments. In addition, Blanchard and Giavazzi (2002) note that the growth rate of income can also affect the current account, as it not only is an 
indicator of future growth prospects, but also captures cyclical effects of output movements on the current account.

8. But current account deficits can also influence growth, in two ways. Most obviously, external borrowing removes constraints on investment and consumption. Investment is no longer constrained by domestic savings, and domestic expenditure (on both investment and consumption) is no longer constrained by domestic income. ${ }^{2}$ This suggests that current account deficits have a direct, positive effect on growth.

9. A second effect is suggested by open-economy versions of the neoclassical growth model, as elaborated, for example, by Barro and Sala-i-Martin (2000). If international capital were perfectly mobile and borrowers were unconstrained, convergence would be achieved instantly. A more realistic variant of the model incorporates constraints on international credit. Specifically, if some forms of capital (e.g., human capital) provide unacceptable security for loans, while other forms of physical capital are acceptable because creditors can take possession in the event of default, then foreign debt can be positive but cannot exceed the quantity of physical capital. In such a model, Barro and Sala-i-Martin write, "the opportunity to borrow on the world credit market ... will turn out to affect the speed of convergence" (p. 105). Empirically, this suggests that the coefficient on per capita income in standard growth regressions may itself be influenced by the current account, as explained below.

\section{Empirical specification}

10. Two equations, one for the current account and one for growth, are estimated simultaneously. The first equation is a modified growth regression, which allows for variation in the speed of convergence:

$$
\Delta y_{i t}=x+\left(\alpha_{1 t}+\alpha_{2} c a_{i t-1}\right)\left(y_{i t-1}-y_{t-1}^{*}\right)+\alpha_{3} c a_{i t-1}+\alpha_{4} Z_{1, i t}
$$

In equation (1), growth in per capita income in country $i$ in year $t, \Delta y_{i t}$, depends on lagged income relative to the steady state income level, $\left(y_{i t-1}-y_{t-1}^{*}\right)$. The steady state income level, $y_{t}^{*}$, is allowed to change over time but is assumed to be the same for all countries in the sample. If poor countries grow faster as they converge to income levels of their richer neighbors, then the coefficient on lagged relative income should be negative. Here, this "speed of convergence" coefficient consists of two parts: a part that is influenced by the current account, $\alpha_{2} c a_{i t-1}$, and an independent part, $\alpha_{1 t}$. If current account deficits $\left(c a_{i t}<0\right)$ accelerate income convergence, then coefficient $\alpha_{2}$ should be positive. The specification

\footnotetext{
${ }^{2}$ A second mechanism through which openness can affect growth is technological spillover effects. As Barro and Sala-i-Martin (2000) note, trade, and especially investment linkages, may promote greater technological diffusion from leader countries to follower countries.
} 
also allows for the possibility that the current account influences actual growth directly, and this effect is captured by the terms $\alpha_{3} c a_{i t-1}$. In addition, growth is allowed to be influenced by standard neoclassical growth controls, such as the proportion of the population with secondary schooling, population growth, and the investment-to-GDP ratio, which are included in matrix $Z_{1, i t}$. Finally, growth is also influenced by the rate of technological progress, $x$. However, time variation in this and in other global cyclical factors suggest augmenting equation (1) by a year dummy, $D_{t}$ which equals one in year $t$ and zero otherwise. The equation can be rewritten as:

$\Delta y_{i t}=\alpha_{0 t}+\left(\alpha_{1 t}+\alpha_{2} c a_{i t-1}\right) y_{i t-1}+\alpha_{3} c a_{i t-1}+\alpha_{4} Z_{1, i t}+\left(u_{1 t}+v_{1 i}+\varepsilon_{1 i t}\right)$

where the term $\alpha_{0 t} \equiv x-\alpha_{1 t} y_{t-1}^{*}+\alpha_{5} D_{t}$, and $\left(u_{1 t}+v_{1 i}+\varepsilon_{1 i t}\right)$ represents a mean-zero composite error term.

11. Equation (3) - the second simultaneous equation of the model-describes the dynamics of the current account. The current account-to-GDP ratio in country $i$ in year $t$, $c a_{i t}$, depends on the current level of income, $y_{i t}$, on current growth, $\Delta y_{i t}$, and on the dependency ratio, $Z_{2}$ :

$c a_{i t}=\beta_{1 t}\left(y_{i t}-y_{t}^{*}\right)+\beta_{2 t} \Delta y_{i t}+\beta_{3} Z_{2, i t}$

The specification, which is identical to the one used by Blanchard and Giavazzi (2002), allows the effect of income per capita on the current account to vary over time. If the process of increasing financial integration in Europe has enabled poor countries to borrow more and rich countries to lend more, then one would expect the coefficient on relative income, $\beta_{1 t}$ to increase over time. Current growth also enters the equation, both as a predictor of future income and in order to capture cyclical effects of output movements on the current account. The effect of growth on the current account is also allowed to vary over time. The dependency ratio captures intertemporal effects of demographic changes. Other things equal, a country with a relatively high dependency ratio is expected to save less. ${ }^{3}$ Finally, as in the growth equation, the equation has a common time effect, captured by the year dummy, $D_{t}$.

The equation can thus be rewritten as:

$c a_{i t}=\beta_{0 t}+\beta_{1 t} y_{i t}+\beta_{2 t} \Delta y_{i t}+\beta_{3} Z_{2, i t}+\left(u_{2 t}+v_{2 i}+\varepsilon_{2 i t}\right)$

where the term $\beta_{0 t} \equiv-\beta_{1 t} y_{t}^{*}+\beta_{4} D_{t}$, and $\left(u_{2 t}+v_{2 i}+\varepsilon_{2 i t}\right)$ represents a mean-zero composite error term.

${ }^{3}$ Following Blanchard and Giavazzi (2002), the dependency ratio is constructed as the ratio of population to the labor force. 
12. The estimation method used is three-stage least squares (3SLS), a standard technique for simultaneous estimation of simultaneous equations in the panel data context. This method, first proposed by Zellner and Theil (1962), permits the estimation a system of equations, in which some of the explanatory variables are endogenous. Here, both the current account and growth are explanatory variables and are endogenous. The three-stage least squares procedure uses an instrumental variable approach to produce consistent estimates and generalized least squares (GLS) to account for the correlation structure in the disturbances across the equations. For further discussion of the 3SLS approach to estimation, see, for instance, Greene (2003, pp. 405-407).

13. Once the parameters have been estimated, the model can be used to generate predicted values of the current account and growth, along with 95 percent confidence intervals. These benchmark values can be compared with actual outcomes to assess the performance of growth and the current account. The (in-sample) predicted values are obtained using the equations:

$\Delta \hat{y}_{i t}=\hat{\alpha}_{0 t}+\left(\hat{\alpha}_{1 t}+\hat{\alpha}_{4} c a_{i t-1}\right) y_{i t-1}+\hat{\alpha}_{2} c a_{i t-1}+\hat{\alpha}_{3} Z_{1, i t}$

and

$c a_{i t}=\hat{\beta}_{0 t}+\hat{\beta}_{1 t} y_{i t}+\hat{\beta}_{2 t} \Delta y_{i t}+\hat{\beta}_{3} Z_{2, i t}$

where the "^" superscripts denote estimates. For each period $t$, the matrix of prediction standard errors is denoted by $s_{t}$. The standard errors are computed using the following formula:

$s_{t}=\sqrt{x_{t} V x_{t}^{\prime}}$

where $x_{t}$ is the matrix of right-hand-side variables up to and including period $t$, and $V$ is the estimated variance covariance matrix of the parameter estimates. Standard error bands around the predicted values can then be computed using a band of \pm 1.96 times the prediction standard errors.

\section{Data}

14. The sample covers the period 1975-2004 and includes the 25 countries of the EU (EU-25). For the new member states, the sample starts in 1995 to avoid the structural breaks associated with the shift to a market economy. Following Blanchard and Giavazzi (2002), income per capita is constructed using real GDP per capita at purchasing power parity (PPP) from the Penn World Tables, Version 6.1 (CICUP, 2002), extended to 2004 using per capita 
real GDP growth rates from the IMF's World Economic Outlook database. ${ }^{4}$ The current account is measured as a ratio to GDP and is taken from the IMF's International Financial Statistics. ${ }^{5}$ The dependency ratio is constructed using population and labor force data from the Penn World Tables.

\section{Data on the neoclassical growth controls (schooling, investment shares, and} population growth) come from the growth data set compiled by Bosworth and Collins (2003). The Bosworth-Collins data set takes several standard data sets and extends them to cover 84 countries over the 40 -year period to 2000. Data on education attainment are from Barro and Lee (1993 and 2000). Capital stock and investment data are originally from a World Bank study by Nehru and Dhareshwar (1993), modified and extended to 2000 by Bosworth and Collins. And data on population growth are from the Penn World Tables. The Bosworth-Collins country sample, however, does not cover any of the countries from central and eastern Europe, so data for these countries was taken from Doyle, Kuijs and Jiang (2001) and cover the period 1996-2004. Data for many of the control variables are, unfortunately, available only up to 2000; schooling data are available only up to 1999 . So the model with the full set of controls is estimated over a restricted sample (1975-99). To establish benchmarks up to 2004, the model is estimated without the additional controls for the full sample (1975-2004).

\section{Results}

\section{Evidence of convergence and of increasing financial integration}

16. A plot of income per capita against subsequent growth over 1975-2004 suggests absolute convergence in Europe. Relatively poor countries with low income per capita are

\footnotetext{
${ }^{4}$ For certain countries, such as Ireland, gross national income (GNI) per capita may be a better proxy for income per capita. However, due to the unavailability of real PPP GNI data, GDP data are used instead.

${ }^{5}$ Data for 2004 are based on the IMF's World Economic Outlook database. Luxembourg is excluded from the sample due to its highly idiosyncratic behavior, with reported current account surpluses that are consistently in the range of 10-15 percent of GDP. The other idiosyncratic cases are (i) Greece in 1975, with a very volatile current account position in the aftermath of the collapse of the military regime - the current account deficit reached 30 percent of GDP; (ii) Ireland in 1978-80, with large unsustainable current account deficits following the second oil price shock and large fiscal deficits in excess of 12 percent of GDP; (iii) Portugal in 1975-82, during which the current account and growth were very volatile in the aftermath of revolution, the loss of colonies, the second oil price shock, and the loss of control of fiscal policy. These three cases are dealt with by introducing country dummies interacted with the specific years in question.
} 
growing relatively quickly, as they catch up with the higher income levels of their richer neighbors (Figure 3). The best-fit line is significant, with a $p$-value of less than 1 percent.

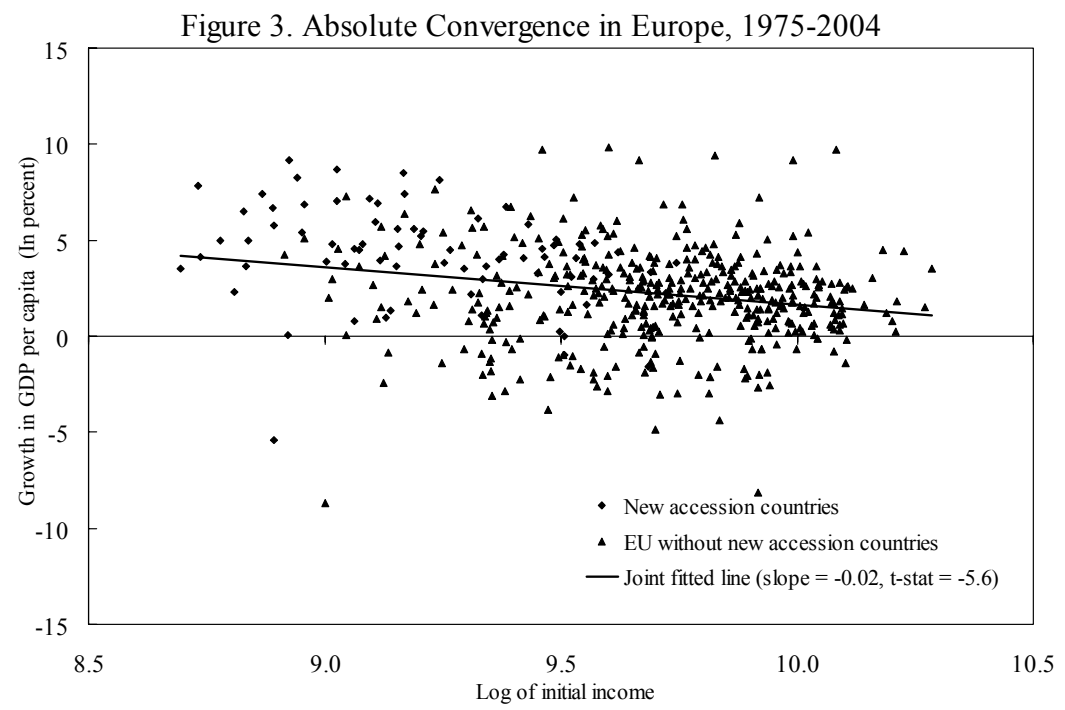

17. This finding is supported by the regression results. We begin by plotting the set of estimated coefficients $\alpha_{1 t}$ and $\beta_{1 t}$ against time. As these are time-varying, it is easiest to view them in a chart rather than in a table. Results are reported for both the EU-25 countries and a subset, the EU-15, namely, the EU-25 minus the 2004 accession countries. Figure 4 shows estimates of the speed of convergence parameter, $\alpha_{1 t}$. For the EU-25, the coefficient is negative most of the time, in line with the hypothesis of absolute income convergence. The estimate, however, only becomes significant at the 5 percent level in the five years following 1999, as well as in 1990 and 1997. For the EU-15, $\alpha_{1 t}$ is again negative most of the time but insignificant at the five percent level in all but three periods. Although this suggests that convergence is faster in the new accession countries, it also reflects the fact that much of the convergence process has been completed for the EU-15, so that the convergence parameter for this subset of countries is less precisely estimated. 
Figure 4. Estimates of the Speed-of-Convergence Parameter, 1975-2004 1/

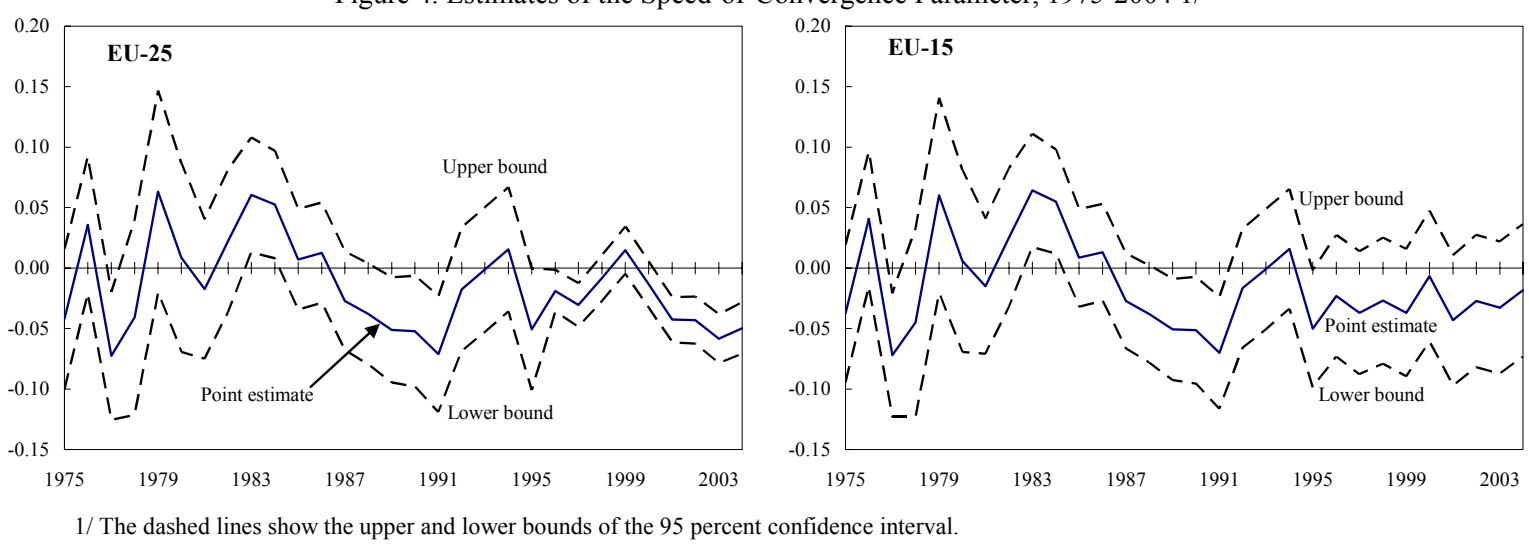

Figure 5. Impact of Income Per Capita on Current Account, 1975-2004 1/
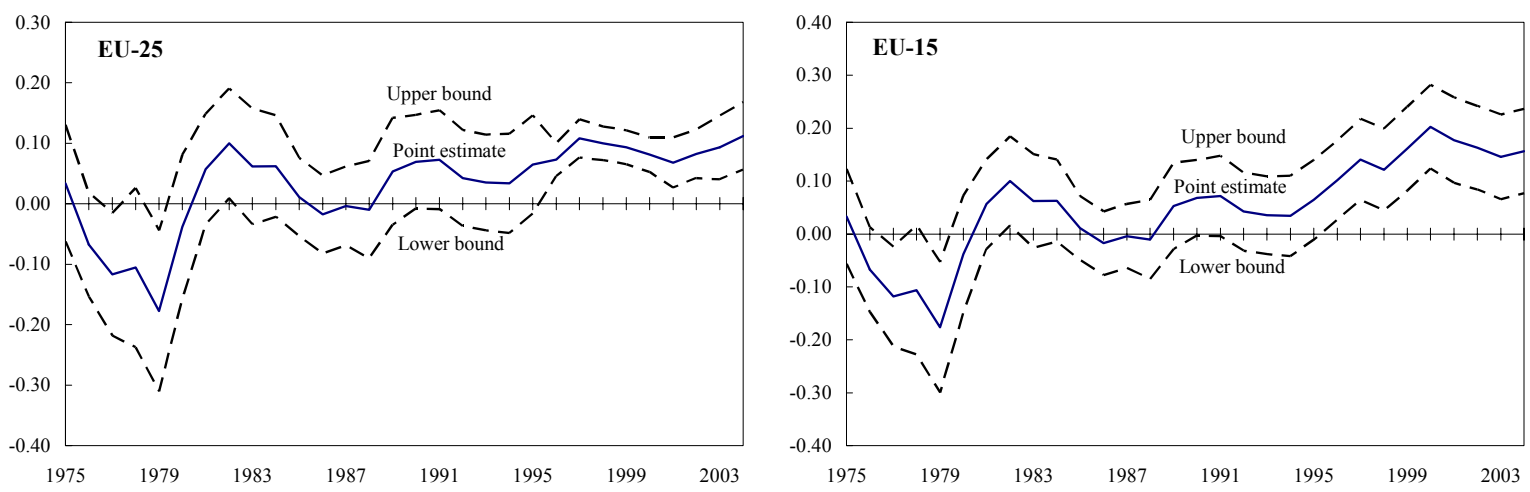

1/ The dashed lines show the upper and lower bounds of the 95 percent confidence interval.

\section{The regressions also find that relative income significantly affects the current}

account. Figure 5 shows estimates of $\beta_{1 t}$, the effect of relative income on the current

account. For both sets of countries, the coefficient is nearly always positive, in line with the intuition that relatively poor countries run larger current account deficits. For both sets of countries, the effect also becomes significant (at the five percent level) only in the late 1990s. The increased dependence of the current account on income is in line with the Blanchard and Giavazzi (2002) finding that greater financial integration in Europe in the 1990s allowed relatively poor countries to borrow more from their richer neighbors. However, there is a more obvious increasing trend in the parameter for the EU-15, and the estimated coefficients reach a higher value by the sample's end. For example, the estimated coefficient of 0.2 in 2000 for the EU-15 sample implies, that, other things equal, for a country with an income per capita that is 40 percent below the EU steady state level (roughly the case of Hungary, if one proxies the steady state with average EU income), the current account-to-GDP ratio should be about 8 percentage points lower than the EU steady state. However, the estimated coefficient of about 0.1 for the EU-25 implies, that, other things equal, a country with an income per capita about 40 percent below the EU steady state should have a current account-to-GDP ratio only about 4 percentage points lower than the EU steady state. A 
plausible explanation for this greater EU-15 effect is that the EU-15 has been more integrated financially than the EU-25 over the sample period.

\section{Estimates of the remaining model parameters indicate that current account} deficits raise the speed of convergence. Table 1 displays the estimates of a selection of the remaining model parameters. The estimate of parameter $\alpha_{2}$-which measures the impact of current accounts on the speed of convergence-is positive and significant at the 1 percent level, in line with the hypothesis discussed in paragraph 10 that current account deficits increase the speed of convergence. A 1 percentage point increase in the current account deficit raises the speed of convergence by 0.26 percentage point per year. In addition, the estimate of $\alpha_{3}$ is negative and significant, suggesting that the current account also affects growth directly. Overall, the model's fit is good, with an $R^{2}$ of 51 and 58 percent for the growth and current account equations, respectively.

\section{Table 1. Estimates of Current Account Effect on Growth}

$$
\begin{gathered}
\text { Estimation of equations: } \\
\Delta y_{i t}=\alpha_{0 t}+\left(\alpha_{1 t}+\alpha_{2} c a_{i t-1}\right) y_{i t-1}+\alpha_{3} c a_{i t-1}+\alpha_{4} Z_{1, i t}+\left(u_{1 t}+v_{1 i}+\varepsilon_{1 i t}\right) \\
c a_{i t}=\beta_{0 t}+\beta_{1 t} y_{i t}+\beta_{2 t} \Delta y_{i t}+\beta_{3} Z_{2, i t}+\left(u_{2 t}+v_{2 i}+\varepsilon_{2 i t}\right)
\end{gathered}
$$

\begin{tabular}{|c|c|c|c|c|c|c|c|c|}
\hline Column Number & \multirow{2}{*}{\multicolumn{2}{|c|}{$\begin{array}{c}1 \\
\text { Baseline }\end{array}$}} & \multicolumn{2}{|c|}{2} & \multicolumn{2}{|c|}{3} & \multicolumn{2}{|c|}{4} \\
\hline Specification & & & Excl. N & Members & Count & Dummies & Neoclas & Dep. Ratio \\
\hline Country Group & \multicolumn{2}{|c|}{ EU-25 } & \multicolumn{2}{|c|}{ EU-15 } & \multicolumn{2}{|c|}{ EU-25 } & \multicolumn{2}{|c|}{ EU-25 } \\
\hline Period & \multicolumn{2}{|c|}{ 1975-2004 } & \multicolumn{2}{|c|}{$1975-2004$} & \multicolumn{2}{|c|}{ 1975-2004 } & \multicolumn{2}{|c|}{ 1975-1999 } \\
\hline Coefficient & $\alpha_{2}$ & $\alpha_{3}$ & $\alpha_{2}$ & $\alpha_{3}$ & $\alpha_{2}$ & $\alpha_{3}$ & $\alpha_{2}$ & $A_{3}$ \\
\hline Estimate & 0.26 & -2.40 & 0.29 & -2.74 & 0.44 & -4.07 & 0.48 & -4.48 \\
\hline Standard Error & $(0.07)$ & $(0.68)$ & $(0.09)$ & $(0.89)$ & $(0.08)$ & $(0.74)$ & $(0.11)$ & $(1.07)$ \\
\hline$p$-value & 0.00 & 0.00 & 0.00 & 0.00 & 0.00 & 0.00 & 0.00 & 0.00 \\
\hline$R^{2}$ of growth equation & \multicolumn{2}{|c|}{0.51} & \multicolumn{2}{|c|}{0.49} & \multicolumn{2}{|c|}{0.57} & \multicolumn{2}{|c|}{0.52} \\
\hline$R^{2}$ of c.a. equation & \multicolumn{2}{|c|}{0.58} & \multicolumn{2}{|c|}{0.56} & \multicolumn{2}{|c|}{0.63} & \multicolumn{2}{|c|}{0.57} \\
\hline
\end{tabular}

20. These results are robust to changes in model specification. First, the robustness of the results is tested to exclude the new member states, and the results appear in column 2 . For this subset of countries, the EU-15, the signs of the estimates of $\alpha_{2}$ and $\alpha_{3}$ remain unchanged, although the magnitude and significance of these coefficients increase slightly. Second, the robustness to including country dummies is tested and the results appear in column 3. The inclusion of country dummies strengthens both the direct effect of the current account on growth, and its indirect effect via the speed of convergence. Finally, we find that the results are robust to including all the standard neoclassical controls. As noted above, the sample using all the controls is shorter, as schooling data is available only to 1999, and the other neoclassical controls are available only to 2000. 
21. The baseline estimates of the convergence speeds have implications for the number of years needed to converge to the steady state. A useful measure of this convergence time is the half-life, which measures the number of years needed to halve the gap between the current income level and the steady state. To estimate the half-life, the estimates of parameters $\alpha_{1 t}$ and $\alpha_{2}$ are used in Equation (8); the last available value of $\alpha_{1 t}$, that for 2004, is used. To illustrate how current account deficits can accelerate the process of convergence, the half-lives are computed for a number of possible current account deficits. The half-life estimates appear in Table 2, along with estimates of the three-quarter lives, computed using Equation 9. As Table 2 suggests, raising the current account deficit from zero to 5 percent of GDP reduces the three-quarter-life from 31 to 24 years.

$$
\begin{gathered}
\text { half life }=\left|\frac{\ln (1 / 2)}{\ln \left(\alpha_{1 t}+\alpha_{2} c a_{i t-1}\right)}\right| \\
\text { three quarter life }=\left|\frac{\ln (1 / 4)}{\ln \left(\alpha_{1 t}+\alpha_{2} c a_{i t-1}\right)}\right|
\end{gathered}
$$

Table 2. Estimated Convergence Half and Three-Quarter Lives (In years)

\begin{tabular}{ccccccc}
\hline & \multicolumn{6}{c}{ Current Account Deficit (Percent of GDP) } \\
\cline { 2 - 7 } & 0 & 1 & 2 & 3 & 4 & 5 \\
\cline { 2 - 7 } Years to narrow gap by one-half & 15 & 15 & 14 & 13 & 13 & 12 \\
Date & 2019 & 2019 & 2018 & 2017 & 2017 & 2016 \\
Years to narrow gap by three-fourths & 31 & 29 & 28 & 26 & 25 & 24 \\
Date & 2035 & 2033 & 2032 & 2030 & 2029 & 2028 \\
\hline
\end{tabular}

\section{Model predictions for current account and growth}

22. The model's predicted values can be used as benchmarks for evaluating how much of growth and the current account can be explained using catch-up considerations. Figures 6 through 8 show the (in-sample) predictions of the current account and growth, along with 95 percent confidence intervals. Because the model is based on the premise of intertemporal optimization, subject to the intertemporal budget constraint, the current account predictions are consistent with sustainability.

\section{The model predicts higher growth and a smaller current account deficit for} Hungary than is presently the case (Figure 6). As a result of the crisis in 1994-95, growth remained below its catch-up potential growth rate in 1996 and 1997. But from 1998 to 2000, Hungary grew at or above the model's predicted growth rate, at rates of 4-5 percent. Since 2001, growth has slowed, both in absolute terms and relative to the model prediction. By 2004 , actual growth of 4 percent was approximately 1 percentage point below the central prediction of the model. The current account deficit (Figure 6, right panel) was smaller than predicted in 1996-97, following the macroeconomic adjustment to the crisis. But since then 
it has widened substantially. The 2004 current account deficit of about 9 percent of GDP is about 2 percentage points higher than what the model predicts.

Figure 6. Hungary: Growth and Current Account Predictions, 1997-2004 1/

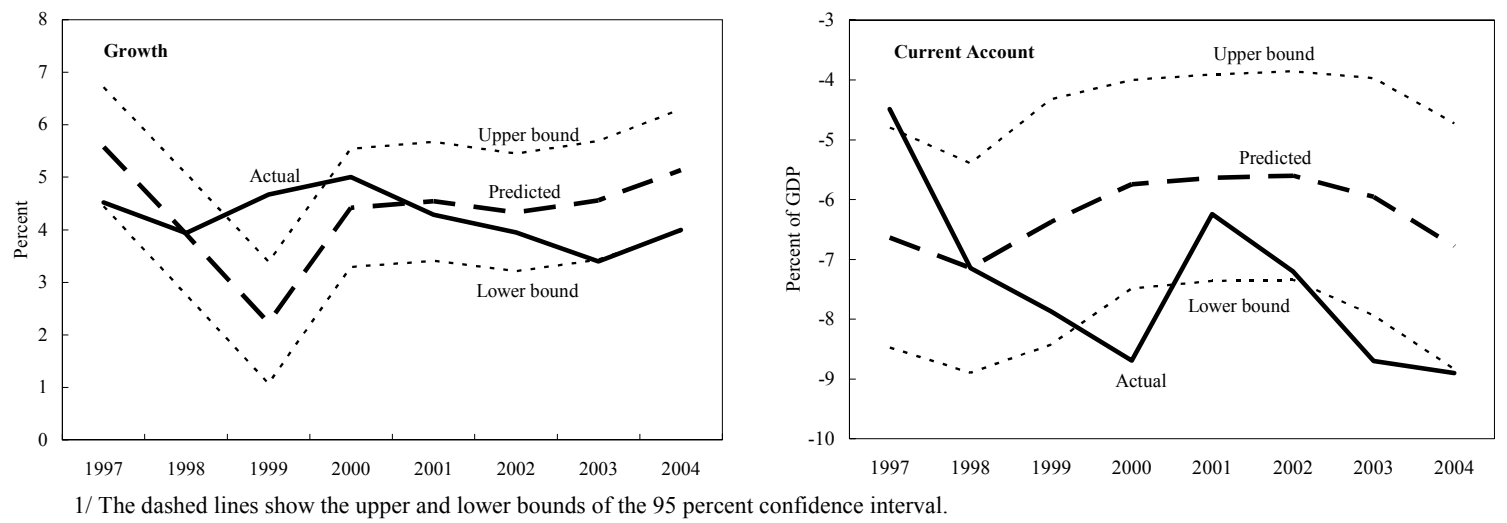

24. Lithuania is an example of a country where current performance seems to be more closely in line with the model's predictions (Figure 7). ${ }^{6}$ Lithuania's recession in 1999 is associated with the Russian financial crisis. But, apart from this contraction, Lithuania's growth performance has roughly been in line with the model's predicted growth rate; its current growth rate of about 7 percent coincides with the model's central prediction. The current account deficit has also been in line with the model's prediction, and in recent years has been smaller than what the model suggests.

Figure 7. Lithuania: Growth and Current Account Predictions, 1996-2004 1/

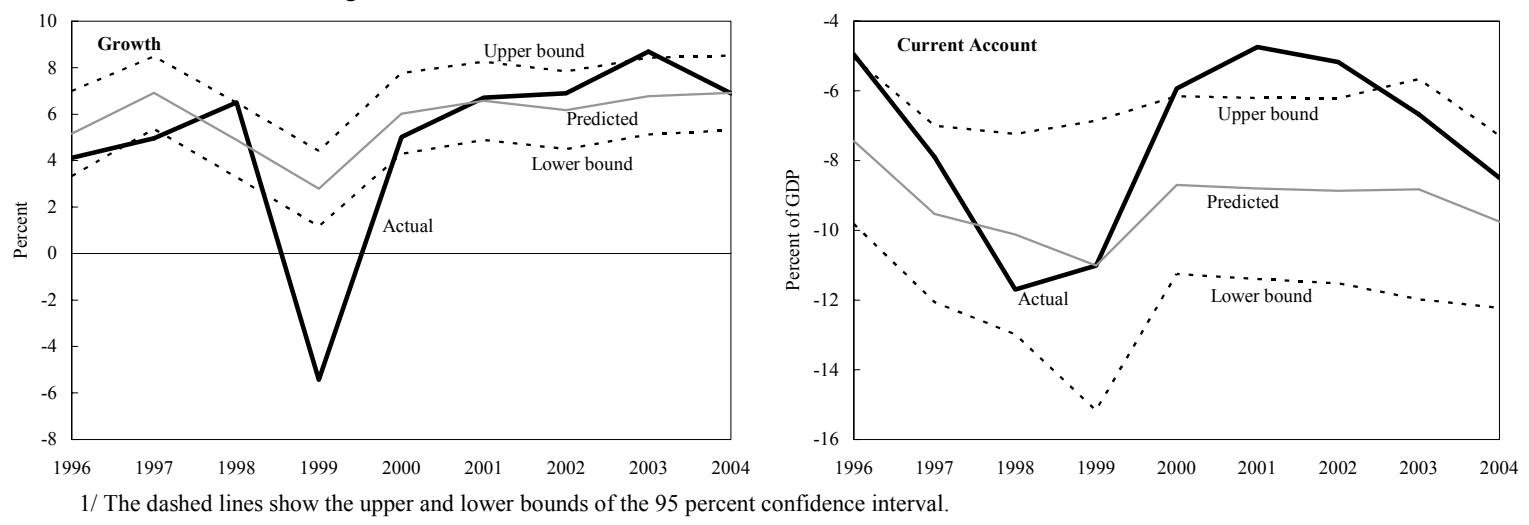

25. As Hungary's income per capita increases, it is expected to run smaller current account deficits and to experience lower growth. Taking as an example a relatively rich country, such as France, the model predicts a current account position near to balance or in

\footnotetext{
${ }^{6}$ This finding for Lithuania is consistent with the results obtained using a simplified version of the model in a selected issues paper for the Lithuania 2004 Article IV Consultations.
} 
surplus, with growth in the 1-2 percent range. As Figure 8 suggests, this prediction fits the experience of France well.

Figure 8. Growth and Current Account Predictions for France, 1985-2004 1/

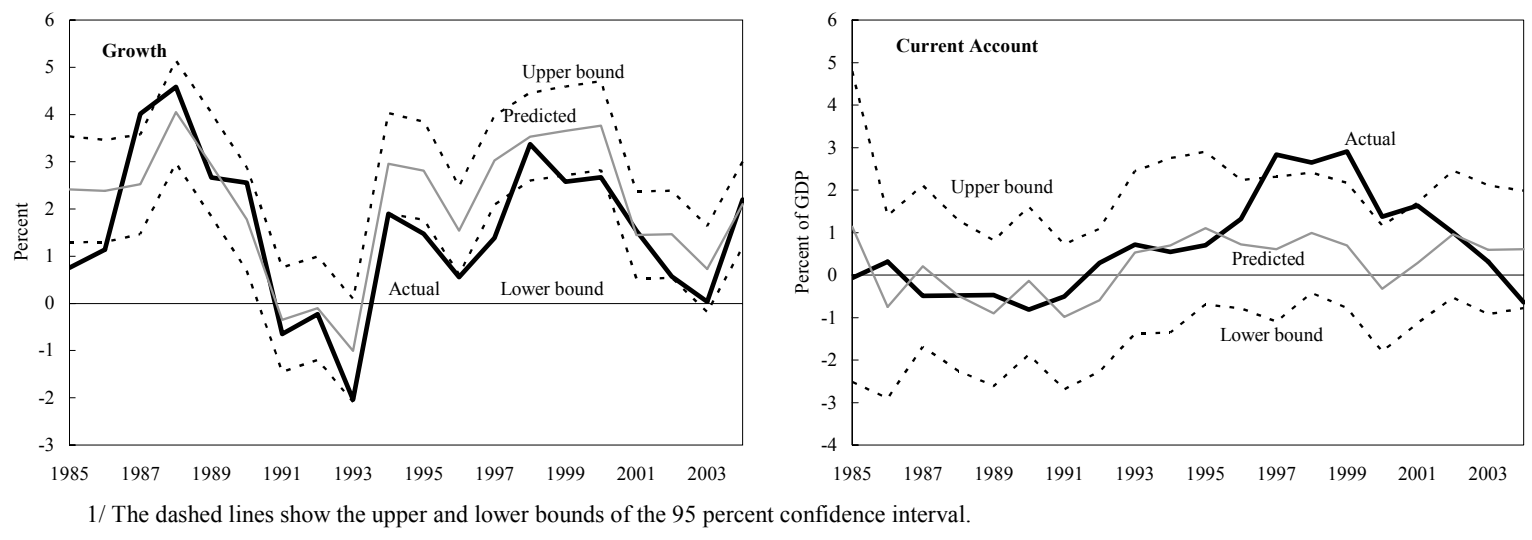

\section{E. Conclusions}

26. This chapter describes a simple empirical model that provides benchmarks to evaluate Hungary's current growth and current account performance. The model, described in more detail in a forthcoming working paper, was developed to explore whether larger current account deficits allow lower-income countries of the EU to converge more quickly to the income levels of advanced EU countries. It also recognizes that, while growth can be influenced by the running of external deficits, the latter can also be influenced by growth. The model does this by combining a modified neoclassical growth regression with a current account regression similar to the one used by Blanchard and Giavazzi (2002). Predictions of the model are used as benchmarks for countries' current performance.

27. The chapter has two main findings. First, the cross-country analysis suggests that, in general, larger current account deficits (capital inflows) are associated with faster income convergence. Second, the model's benchmark for Hungary suggests that its current account deficit has been larger than would be expected based on the income convergence process. Hungary's current account deficit of 9 percent of GDP was about $2 \frac{1}{2}$ percent of GDP higher than the central prediction of the model. Though just within the 95 percent confidence band, growth was about 1 percentage point less than the central prediction. 


\section{REFERENCES}

Barro, Robert J., and Jong-Wha Lee, 1993, "International Comparisons of Educational Attainment," Journal of Monetary Economics Vol. 32 (December), pp. 363-94.

, 2000, "International Data on Educational Attainment: Updates and Implications." NBER Working Paper No. 7911 (Cambridge, Massachusetts: National Bureau of Economic Research).

_ MIT Press).

Blanchard, Olivier, and Francesco Giavazzi, 2002, "Current Account Deficits in the Euro Area: The End of the Feldstein-Horioka Puzzle?" Brookings Papers on Economic Activity: 2, Brookings Institution, pp. 147-209.

Bosworth, Barry, and Susan M. Collins, 2003, "The Empirics of Growth: An Update," Brookings Papers on Economic Activity: 2, Brookings Institution, pp. 113-206.

CICUP, 2002, Penn World Tables, Version 6.1 (Philadelphia, Pennsylvania: Center for International Comparisons at the University of Pennsylvania).

Doyle, Peter, Louis Kuijs, and Guorong Jiang, 2001, "Real Convergence to EU Income Levels: Central Europe from 1990 to the Long Term", IMF Working Paper 01/146 (Washington: International Monetary Fund).

Greene, William H., 2003, Econometric Analysis, $5^{\text {th }}$ ed. (Upper Saddle River, New Jersey: Prentice-Hall).

Nehru, Vikram, and Ashok Dhareshwar, 1993, “A New Database on Physical Capital Stock: Sources, Methodology and Results," Revista de Análisis Económico, Vol. 8 (June), pp. 37-59.

Zellner, Arnold, and Henri Theil, 1962, “Three-Stage Least Squares: Simultaneous

Estimation of Simultaneous Equations," Econometrica, Vol. 30 (January), pp. 54-78. 


\section{FisCAL Commitment: The Role OF BUdget Institutions ${ }^{7}$}

\section{A. Introduction}

28. In its effort to join the Economic and Monetary Union (EMU), Hungary is facing the challenge of consolidating its fiscal position. The authorities aim to adopt the euro by 2010, which presents a significant challenge, given the current fiscal position and the need to meet the Maastricht fiscal deficit criterion by mid-2007 (Table 1). The authorities' fiscal consolidation path envisages a fiscal deficit reduction of 0.6 percent of GDP annually, as spelled out in their updated Convergence Program (CP). Adopting the euro also implies that Hungary will have to aim at an even more ambitious fiscal consolidation objective in the longer run: a balanced structural fiscal budget.

Table 1. Hungary: Selected Fiscal Indicators, 2000-04 1/

(In percent of GDP, unless otherwise specified)

\begin{tabular}{|c|c|c|c|c|c|}
\hline & 2000 & 2001 & 2002 & 2003 & $\begin{array}{r}2004 \\
\text { Est. }\end{array}$ \\
\hline \multicolumn{6}{|l|}{ Consolidated general govenrment } \\
\hline Total revenue $2 /$ & 46.0 & 45.2 & 44.6 & 43.7 & 45.1 \\
\hline Total expenditure & 48.8 & 49.7 & 54.0 & 50.9 & 50.4 \\
\hline Of which : interest payments & 5.6 & 4.9 & 4.1 & 4.0 & 4.5 \\
\hline Balance 2/ & -2.8 & -4.5 & -9.4 & -7.2 & -5.4 \\
\hline Net interest & -4.8 & -4.2 & -3.8 & -3.8 & -4.2 \\
\hline Primary balance $2 /$ & 2.1 & -0.3 & -5.6 & -3.4 & -1.2 \\
\hline \multicolumn{6}{|l|}{ Memorandum items: } \\
\hline GDP, in current prices (billions of forints) & 13,172 & 14,850 & 16,740 & 18,568 & 20,216 \\
\hline Gross debt & 55.4 & 53.5 & 57.1 & 59.1 & 60.7 \\
\hline
\end{tabular}

29. Modest fiscal consolidation has been achieved in the last two years, but the government has not delivered on its fiscal deficit targets, which have been

systematically revised upward. The persistent overshooting of the deficit targets in the last years reflects a combination of overspending and revenue shortfalls. This was aggravated by the government's inability to adjust to shocks and take prompt measures, which then necessitated the upward revision of fiscal deficit targets several times during the same year (Figure 1).

\footnotetext{
${ }^{7}$ Prepared by Stefania Fabrizio.
} 
Figure 1. Hungary: Fiscal Deficit Performance and Targets, 2002-08 (In percent of GDP)

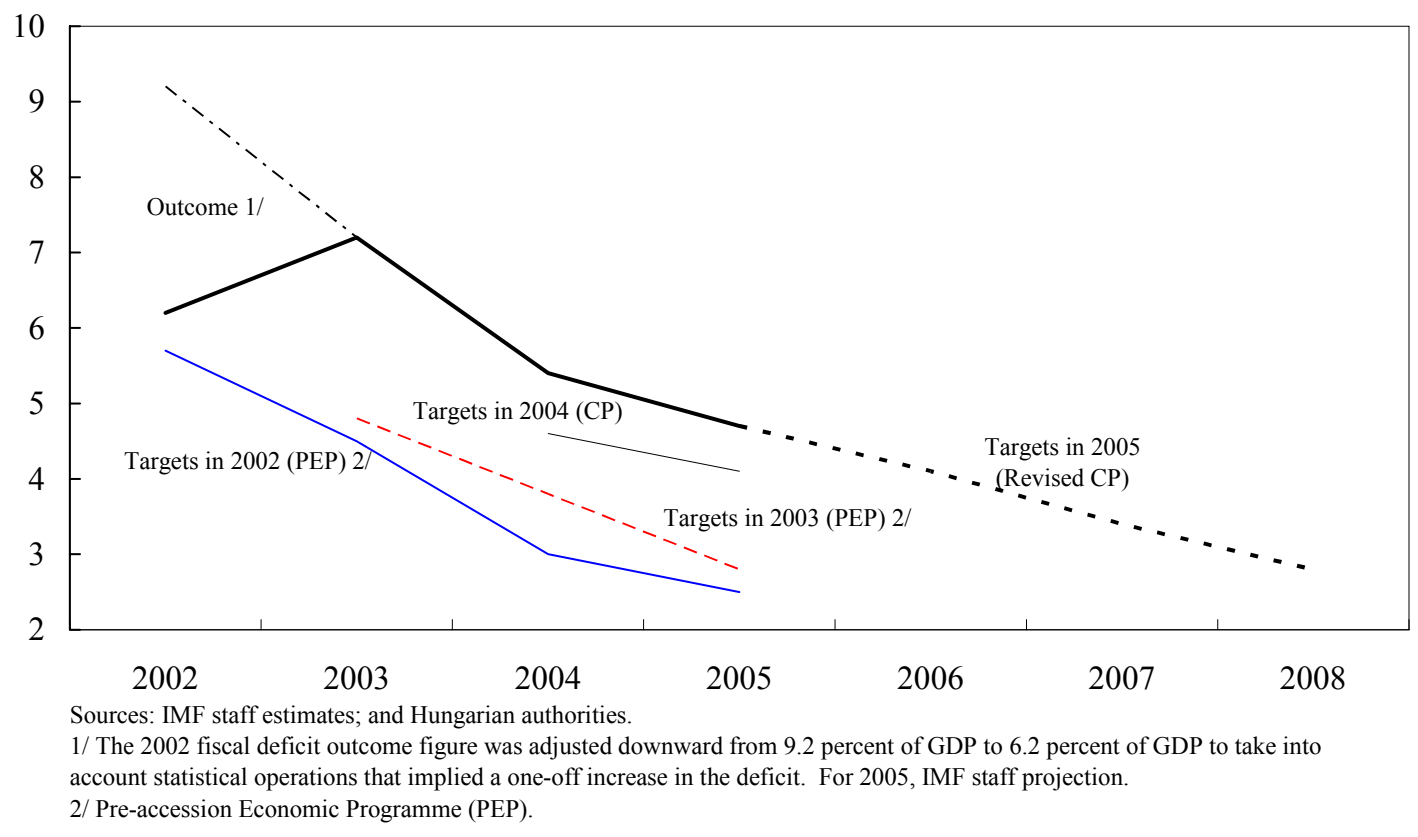

30. A strengthened institutional framework for the budget process could enhance fiscal discipline. To restore credibility to the fiscal policy targets, the institutional structure of the budget process is crucial, as extensively analyzed in the political economy literature during the last decade. ${ }^{8}$ Following this line of research, this paper analyzes the link between the institutional design of the budget process in its three phases (preparation, authorization, and implementation) and fiscal performance in Hungary and in other new and potential European Union (EU) member countries. The paper concludes that budget institutions matter for fiscal performance. While focusing on fiscal institutions, the paper also considers other determinants of fiscal discipline, such as domestic politics and the EU framework. When considered simultaneously, budget institutions continue to be significant for fiscal discipline, while domestic politics appears less relevant. As for the other determinants, the preparation for EU accession seems to have had an expansionary effect on fiscal performance in these countries, as they have had to adjust their budget to take into account new EU-related expenditure, such as cofinancing of EU funds and administrative upgrades. Finally, in analyzing the channels through which fiscal institutions determine fiscal performance, the paper presents evidence that budget institutions affect fiscal performance through government expenditure, while they do not seem relevant to revenue generation.

\footnotetext{
${ }^{8}$ See, among others, von Hagen (1998), Alesina and Perotti (1999), and Persson and Tabellini (2000).
} 
31. The rest of the paper is structured as follows. Subsection B provides a brief theoretical overview on how fiscal institutions affect fiscal performance; presents the index of the quality of fiscal institutions used in the analysis; and provides a brief description of the quality of budget institutions in Hungary. The results of the empirical analysis are shown in Subsection C. Finally, Subsection D concludes.

\section{B. Budget Institutions and their Relevance for Fiscal Performance}

\section{A theoretical overview}

32. The institutional structures of the budget process have an impact on the behavioral incentives and strategic choices of politicians and can thereby affect the policy outcomes arising from collective decision-making processes. Accordingly, different organizational structures of the budget process can have different implications for the size and composition of the budget and its financing. Following Weingast, Shepsle, and Johnson et al. (1981), von Hagen and Harden (1995), and Velasco (1999 and 2000), the budget process can be interpreted as affected by a common-pool resource problem. While the budget financing is shared by all taxpayers, benefits from spending can be targeted. In these circumstances, individual policymakers tend to focus on the full benefits of expanding spending in their districts or relevant policy areas, but take into account only the social marginal costs of higher taxes that affect their constituencies. This incomplete internalization of costs/benefits of expenditures induces overspending on specific areas/projects without consideration for the optimal level that would balance social marginal costs and benefits.

33. The collective action perspective suggests that centralized fiscal authority and cooperative bargaining mechanisms are necessary to overcome the common-pool problem and promote fiscal discipline. A stronger hierarchy reduces the common pool problem by concentrating budgetary power in the hands of key policymakers (e.g., the prime minister or finance minister), who have an incentive to internalize the costs and benefits of public activities. ${ }^{9}$ Cooperative decision making induces policymakers to consider the externality problem when they collectively negotiate on, and mutually commit themselves to, budget targets. These two principles, combined with structures and devices to monitor efficiently and enforce budget decisions, promote fiscal discipline.

34. Therefore, the design of institutional features of the three phases of the budget process (preparation, authorization, and implementation) by a stronger hierarchy, cooperative bargaining, and efficient monitoring rules is key for fiscal discipline. The application of these principles to the design of the institutional characteristics of the budget process has the following implications. For the preparation stage, procedures are needed to guide the establishment of fiscal targets based on a macroeconomic framework. Furthermore, a strong prime/finance minister, who is expected to limit spending pressures by appropriation

\footnotetext{
${ }^{9}$ See, among others, von Hagen and Harden (1995) and Hallerberg and von Hagen (1999).
} 
managers, is crucial. For the authorization phase, limiting the power of parliament to increase the spending and deficit targets set by the government draft budget and establishing a centralized organizational structure of parliament to promote coherent policymaking should mitigate the common-pool problem. For the budget implementation stage, mechanisms are needed to guarantee that the adopted target is duly executed and that adjustments made in case of economic shocks are consistent with sound fiscal policy.

Quantification of the quality of fiscal institutions in new and potential EU members: the link with fiscal performance

35. Bearing in mind these theoretical considerations, an index of the quality of fiscal institutions is constructed for new and potential $\mathrm{EU}$ member countries. Based on information provided directly by the authorities and other sources (Appendix I), a quantitative index of the overall quality of budget institutions (or fiscal institutions; the two terms will be used interchangeably throughout the paper) is constructed for ten countries: Estonia, Bulgaria, the Czech Republic, Hungary, Latvia, Lithuania, Poland, Romania, the Slovak Republic, and Slovenia. The overall index is calculated as the average of three indices, representing the quality of the institutional features of the three phases of the budget process - the preparation, authorization, and implementation stages.

36. For the countries under consideration, the quality of budget institutions appears to be related to fiscal performance. Several factors explain fiscal performance, and these are considered in some detail in the multivariate analysis in Subsection C. However, Figure 2, a bivariate plot of fiscal institutions and fiscal performance, shows the relationship between the quality of fiscal institutions and the primary balance. During the period under consideration 1997-2003, many of these countries changed their fiscal institutions substantially, as part of their reform agenda to transform their economies from transition to market economies.

37. Over the period 1997-2000, these countries experienced important shocks and structural changes, which influenced substantially their fiscal position, making the relationship between budget institutions and fiscal performance less clear. The Russian crisis, for example, affected growth and the fiscal budget in the Baltic countries in 1999. Also the Slovak Republic underwent an important bank restructuring in 2000, with negative consequences for the budget; Romania had general elections in 2000, which had an expansionary effect on the fiscal budget; and Bulgaria introduced a currency board arrangement in 1997, which represented an important device to induce fiscal discipline from the onset.

38. The link between fiscal institutions and fiscal performance became more evident during the period 2001-03. Focusing on this subperiod, the positive relation between the quality of budget institutions and fiscal performance becomes more evident (Figure 2, right panels, and Figure 3). The relationship becomes clearer when Bulgaria, the fiscal performance of which was strongly affected by the introduction of a currency board arrangement in 1997, is excluded from the sample (Figure 2, bottom right panel). 
Figure 2. Fiscal Institutions Quality and Primary Balance
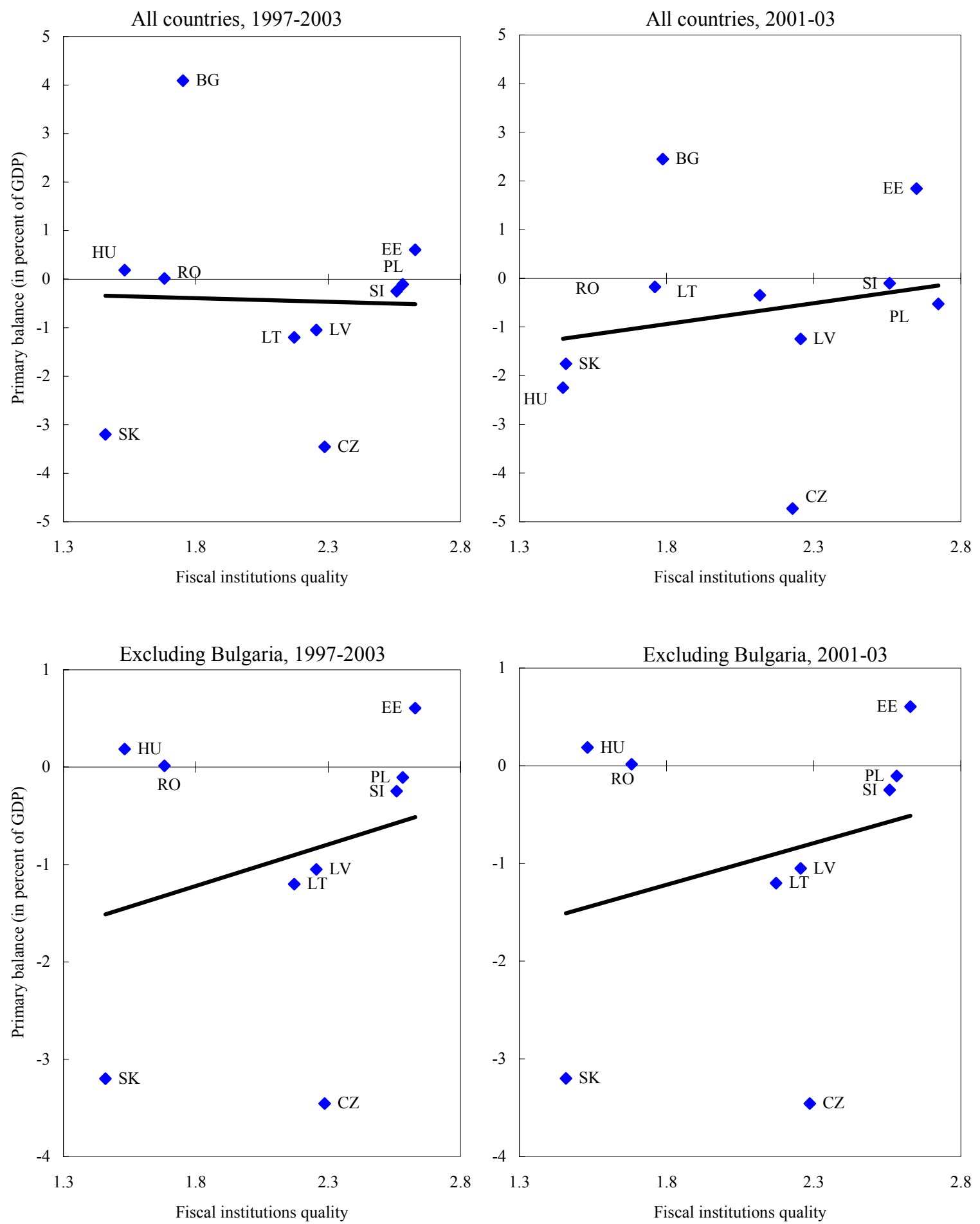

Sources: IMF staff estimates; authorities; and fiscal notifications to the European Commission. 
Figure 3. Fiscal Institutions and Fiscal Performance, 2001-03

- Primary balance (in percent of GDP, LHS)

— Fiscal institutions index, RHS
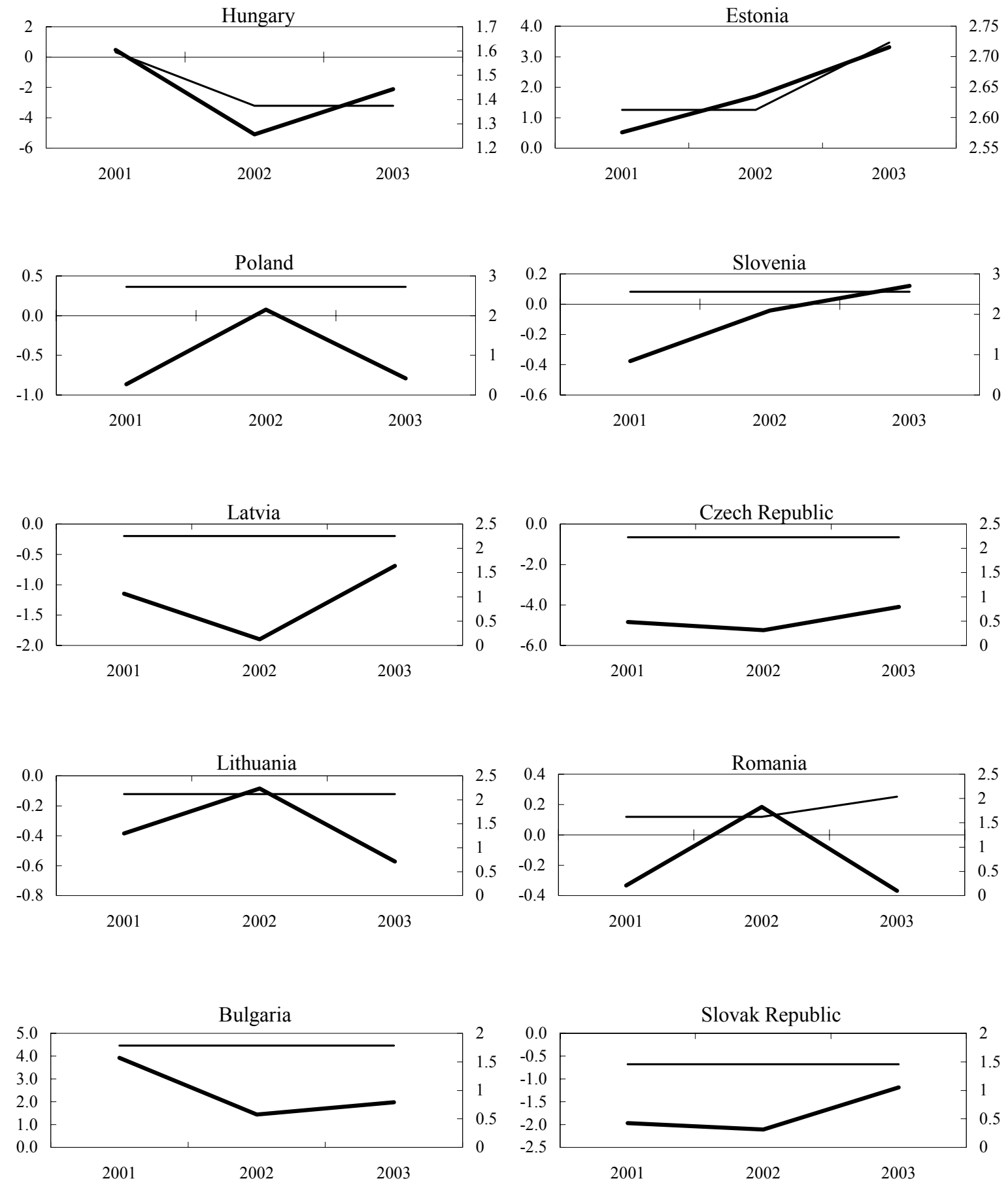

Sources: IMF staff estimates; authorities; and fiscal notifications to the European Commission. 


\section{Quality of budget institutions in Hungary}

39. Turning now to Hungary, budget institutions did not improve over the period 1997-2003: if anything they deteriorated somewhat. Graphically, the link between budget institutions and fiscal performance appears to be strong (Figure 4). With respect to the features considered in this paper (Appendix I), budget institutions in Hungary were not reformed between 1997 and 2002. In 2002, an amendment to the organic budget law was introduced that allowed considerable leeway in undertaking additional spending without supplementary appropriations and parliamentary approval (Appendix I, Tables 1 and 2). ${ }^{10}$ This change meant that the government could, to a certain extent, modify the budget parameters, and the agreements made in the budget planning and authorization phases could be undermined and the parliamentary authorization function weakened. As a consequence, the budget lost some of its commitment function, since a hard constraint was not imposed. Introducing this amendment, therefore, weakened substantially the implementation phase of the budget process, a deterioration that was reflected in that index and consequently the overall index.

Figure 4. Hungary: Budget Institutions and Fiscal Performance, 1997-2003

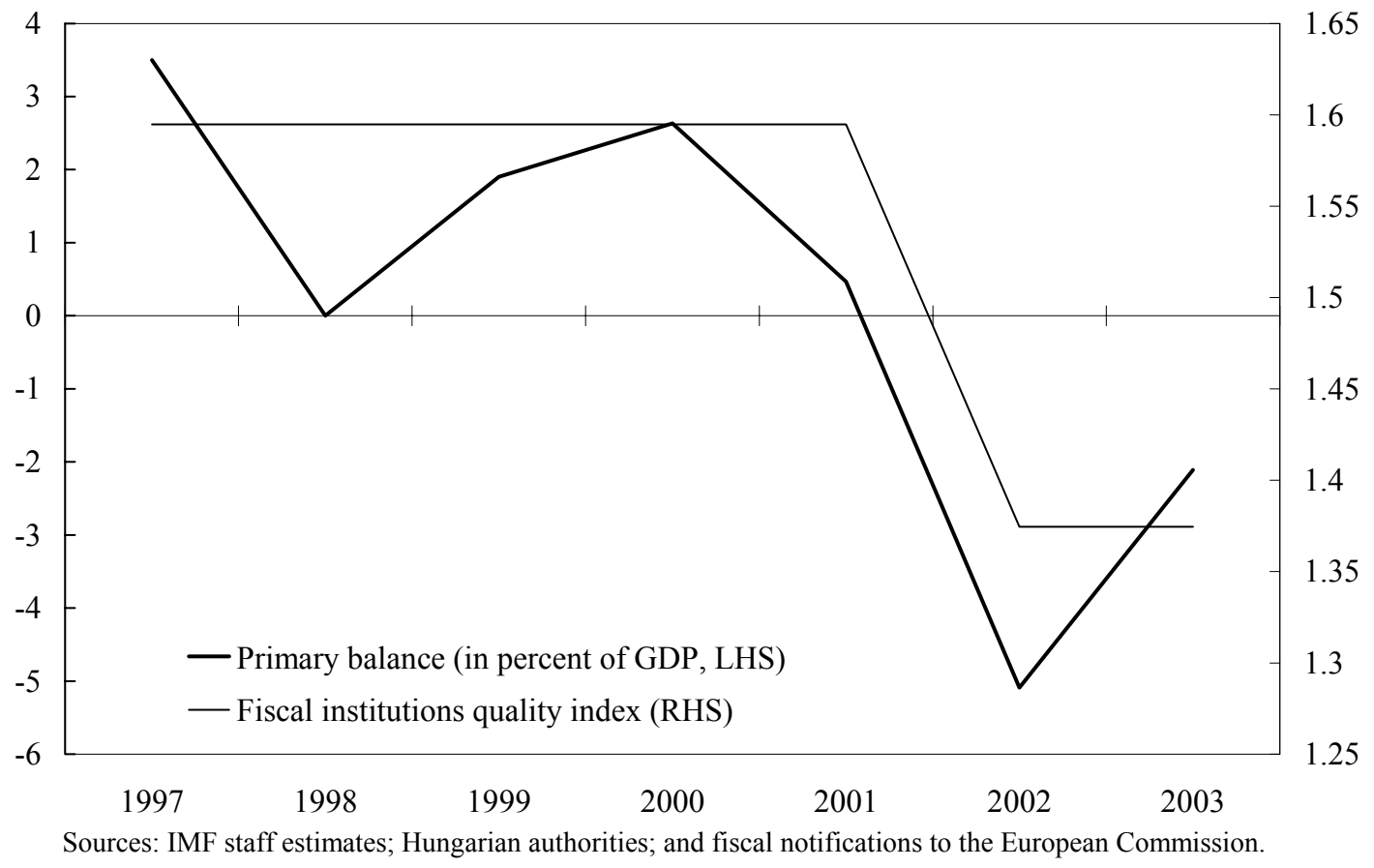

40. The quality of budget institutions in Hungary also deteriorated in relative terms during 1997-2003. Hungary ranks lower in the quality of rules and procedures concerning the budget process relative than the other new and potential EU member countries (Table 2).

${ }^{10}$ See Fiscal ROSC update, July 2004. 
While the quality of budget institutions in Estonia and Slovenia appears to be relative high, Bulgaria, the Slovak Republic, and Hungary bring up the rear, in descending order. Poland made the most significant progress in improving the quality of its budget institutions over the period 1997-2003, as it modified importantly its budget institutions in 1998 and 1999. Changes in that country affected the budget preparation and authorization phases, and included the introduction of a statutory mandated fiscal rule to guide the extent of fiscal deficit targets during the preparation stage; the strengthening of the sequence of the budgetary decision-making process; and the introduction of constraints on the legislature to amend the government's draft budget (Appendix I, Tables 1 and 2).

Table 2. Fiscal Institution Quality Index

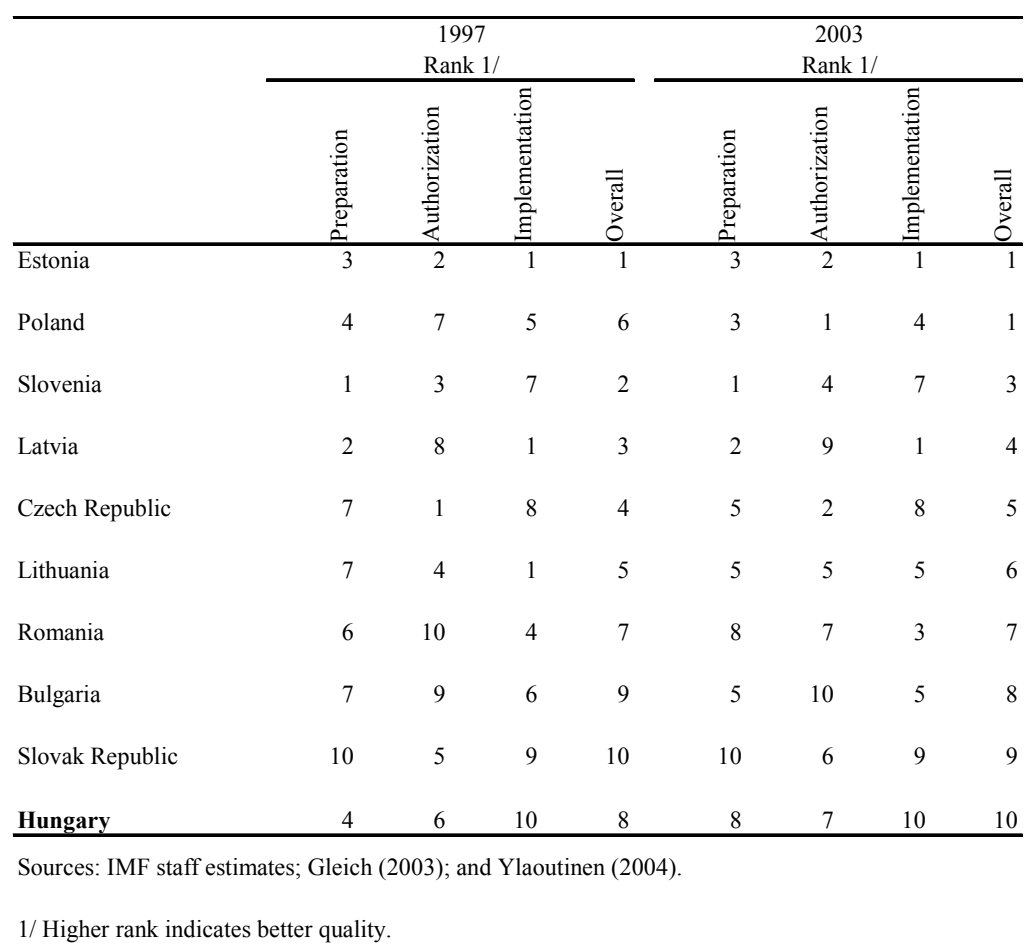

\section{Empirical Results}

41. Budget institutions matter for fiscal performance. The empirical analysis begins with an explanation of the primary budget balance. Table 3 presents cross-section regressions, based on time-averaged variables. Budget institutions are seen to influence budget performance, in line with the findings of Gleich (2003) and Yläoutine (2004) (Table 3 ). While appealing, cross-sectional estimates are subject to bias from omitted variables. Panel regressions with fixed effects allow the exploitation of the time dimension of the fiscal institutions index, thus reducing the omitted-variable bias. The results are displayed in Table 4. Again, budget institutions appear to matter for fiscal performance. Among other control variables considered (Appendix II), the debt position (lagged) is also highly significant in determining the fiscal outcome, implying that countries with larger public debt run larger surpluses (or smaller deficits). 
Table 3. Budgetary Institutions and Fiscal Performance:

Evidence from Cross-Country Regressions

\begin{tabular}{|c|c|c|c|c|c|c|}
\hline & \multicolumn{6}{|c|}{ Primary Balance } \\
\hline & $(1)$ & (2) & (3) & (4) & (5) & (6) \\
\hline Overall index & $\begin{array}{r}2.58 \\
(1.07)^{*}\end{array}$ & $\begin{array}{r}2.61 \\
(1.15)^{*}\end{array}$ & $\begin{array}{r}2.66 \\
(1.35)\end{array}$ & & & \\
\hline Budget preparation index & & & & $\begin{array}{r}2.04 \\
(0.88)^{*}\end{array}$ & & \\
\hline Authorization index (budget approval) & & & & & $\begin{array}{r}1.4 \\
(1.09)\end{array}$ & \\
\hline Budget implementation index & & & & & & $\begin{array}{r}3.2 \\
(2.92)\end{array}$ \\
\hline Debt -to-GDP ratio (lagged) & $\begin{array}{r}0.08 \\
(0.02)^{* * *}\end{array}$ & $\begin{array}{r}0.09 \\
(0.02)^{* *}\end{array}$ & $\begin{array}{r}0.09 \\
(0.03)^{* *}\end{array}$ & $\begin{array}{r}0.06 \\
(0.02)^{* *}\end{array}$ & $\begin{array}{r}0.08 \\
(0.03)^{*}\end{array}$ & $\begin{array}{r}0.11 \\
(0.06)\end{array}$ \\
\hline Dummy for IMF program & $\begin{array}{r}3.43 \\
(1.02)^{* *}\end{array}$ & $\begin{array}{r}3.38 \\
(1.09)^{* *}\end{array}$ & $\begin{array}{r}3.41 \\
(1.25)^{*}\end{array}$ & $\begin{array}{r}2.99 \\
(1.13)^{*}\end{array}$ & $\begin{array}{r}5.01 \\
(2.14)^{*}\end{array}$ & $\begin{array}{l}-0.08 \\
(3.19)\end{array}$ \\
\hline Unemployment rate & & $\begin{array}{r}-0.07 \\
(0.14)\end{array}$ & $\begin{array}{r}-0.07 \\
(0.15)\end{array}$ & $\begin{array}{r}0.1 \\
(0.15)\end{array}$ & $\begin{array}{r}-0.11 \\
(0.19)\end{array}$ & $\begin{array}{r}-0.22 \\
(0.24)\end{array}$ \\
\hline Openness index & & & $\begin{array}{r}0.23 \\
(2.12) \\
\end{array}$ & $\begin{array}{r}0.17 \\
(1.92) \\
\end{array}$ & $\begin{array}{r}-1 \\
(2.38) \\
\end{array}$ & $\begin{array}{r}1.56 \\
(3.44) \\
\end{array}$ \\
\hline Observations & 70 & 70 & 70 & 70 & 70 & 70 \\
\hline Number of nid & 10 & 10 & 10 & 10 & 10 & 10 \\
\hline$R$-squared & 0.38 & 0.4 & 0.4 & 0.35 & 0.29 & 0.5 \\
\hline
\end{tabular}

Source: IMF staff estimates.

Notes: Standard errors in parentheses. * significant at $10 \%$; ${ }^{* *}$ significant at $5 \%$; $* * *$ significant at $1 \%$.

Data description and sources in Appendix II.

Table 4. Budgetary Institutions and Fiscal Performance:

Evidence from Panel Data Regressions (Fixed Effects)

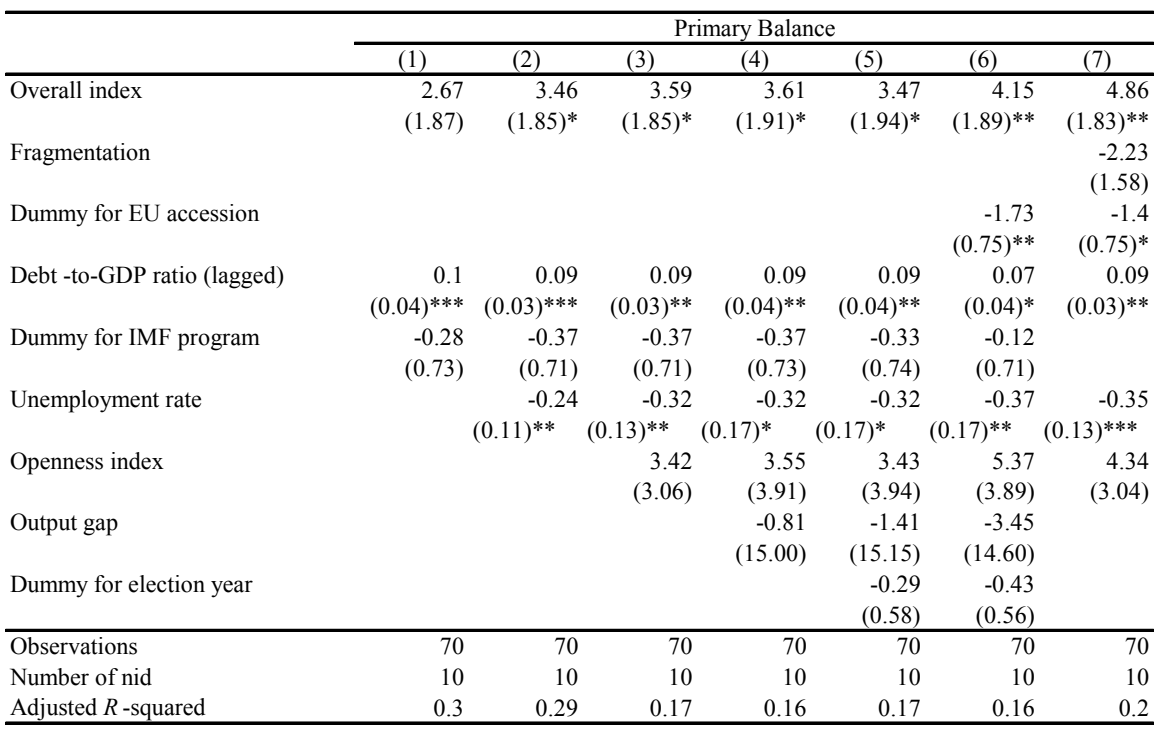

Source: IMF staff estimates.

Notes: Standard errors in parentheses. * significant at $10 \%$; * significant at $5 \%$; *** significant at $1 \%$.

Data description and sources in Appendix II.

42. When the two factors are considered simultaneously, fiscal institutions continue to be significant for fiscal discipline, while domestic politics appears less relevant. This is not to say that, as analyzed extensively in the literature, domestic politics as reflected in 
political structures are not important determinant of fiscal performance. ${ }^{11}$ Given the similarities in the political structures of these countries, to capture the variation in their political arrangements the analysis focuses on the district size (electoral rules) and the government fragmentation (party structure). A larger district elects more legislators in a voting jurisdiction. The district size appears to matter for government spending, as larger voting districts diffuse electoral competition, inducing parties to seek support from broad coalitions in the population. Meanwhile, smaller districts steer electoral competition toward narrower, geographical constituencies. Since broad spending programs are more effective in seeking broad support and targeted programs are more effective in seeking narrow support, electoral rules with larger districts are expected to bias spending toward broad, nontargeted programs (see Persson and Tabellini (1999), and Milesi-Feretti, Perotti, and Rostagno, (2001)). Coalition governments tend to spend more than single-party governments (see, e.g., Kontopoulos and Perotti, (1999)), as they are more affected by the common-pool problem. When these political structures are considered simultaneously with fiscal institutions, however, nonlinear estimates, used to take into account the time-invariant features of the district size variable (Box 1), suggest that budget institutions continue to matter for fiscal performance, while political structures appear less relevant (Table 5). This result has important positive implications for fiscal discipline, because changing fiscal institutions is usually less troublesome than modifying political institutions, as constitutions are not changed often, and the political processes they set in motion have strong inertia.

Table 5. Budgetary Institutions and Fiscal Performance:

Evidence from Nonlinear Least Squares Regressions

\begin{tabular}{lrrrr}
\hline & \multicolumn{4}{c}{ Primary Balance } \\
\cline { 2 - 5 } & \multicolumn{1}{c}{$(1)$} & \multicolumn{1}{c}{$(2)$} & \multicolumn{1}{c}{$(4)$} \\
\hline Overall index & 6.44 & 5.85 & 5.62 & 6.36 \\
& $(1.99)^{* * *}$ & $(1.96)^{* * *}$ & $(1.95)^{* * *}$ & $(1.97)^{* * *}$ \\
Electoral rule & 0.07 & -0.2 & 0.19 & 0.2 \\
& $(0.44)$ & $(0.49)$ & $(0.35)$ & $(0.37)$ \\
Fragmentation & -2.36 & & & -2.64 \\
& $(1.62)$ & & & $(1.58)$ \\
Dummy for EU accession & -0.71 & -1.13 & & \\
Debt -to-GDP ratio (lagged) & $(1.01)$ & $(0.94)$ & & \\
& 0.08 & 0.06 & 0.09 & 0.09 \\
Unemployment rate & $(0.04)^{* *}$ & $(0.04)$ & $(0.04)^{* *}$ & $(0.04)^{* *}$ \\
& -0.33 & -0.33 & -0.25 & -0.29 \\
Openness index & $(0.15)^{* *}$ & $(0.15)^{* *}$ & $(0.14)^{*}$ & $(0.14)^{*}$ \\
& 6.68 & 6.82 & 7.3 & 6.72 \\
Constant & $(3.85)^{*}$ & $(3.84)^{*}$ & $(3.88)^{*}$ & $(3.83)^{*}$ \\
& -18 & -16.75 & -20.96 & -19.78 \\
Observations & $76.29)^{* * *}$ & $(6.09)^{* * *}$ & $(5.99)^{* * *}$ & $(5.94)^{* * *}$ \\
Number of nid & 70 & 70 & 70 & 70 \\
Adj. $R$-squared & 10 & 10 & 10 & 10 \\
\hline
\end{tabular}

Source: IMF staff estimates.

Notes: Standard errors in parentheses. * significant at 10\%; ** significant at 5\%;

*** significant at $1 \%$. Data description and sources in Appendix II.

${ }^{11}$ See, among others, Persson and Tabellini (1999 and 2000) and Persson (2002). 


\section{Box 1. Methodology for Dealing with Time-Invariant Political Structure Variables}

The empirical specification used in the analysis is the following:

$$
y_{i t}=\alpha+v_{i}+\beta_{t} u_{t}+\gamma s_{i t}+\delta x_{i t}+\eta z_{i t}+\varepsilon_{i t}
$$

where $y_{i t}$ is the fiscal outcome in country $i$ and year $t ; u_{t}$ represents variables common to all countries; $v_{i}$ is a country specific component; $s_{i t}$ is the fiscal institutions index; $x_{i t}$ comprises other control variables; and $z_{i t}$ are political institutions variables. When dealing with a time-invariant variable, such as the district size $\left(z_{i t}\right)$, cross-sectional estimates can be used, but they are potentially subject to bias. A way to overcome this problem is, instead of testing for the direct effect of the political variable on the fiscal outcome $\left(H_{0}: \eta=0\right)$, to test whether different political institutions shape different policy responses to unobservable common economic and political events, using the following specific parametrization of $\beta_{i}$ :

$$
y_{i t}=\alpha+\left[1+\lambda\left(z_{i}-\bar{z}\right)\right] \beta u_{t}+\gamma s_{i t}+\delta x_{i t}+\left(v_{i}+\eta z_{i}\right)+\varepsilon_{i t},
$$

where a set of time dummies can be used to estimate $\beta u_{t}$, the common impact on policies of the common event in (2) (Persson, 2002). The crucial parameter $\lambda$ is then estimated by nonlinear least squares, while estimating the fiscal institutions effect and including fixed effects to control for the country-specific averages $\left(v_{i}+\eta z_{i}\right)$.

If the focus is on how political institutions shape the adjustment to observable economic events (e.g., world oil prices), the following parametrization of $\beta_{\mathrm{i}}$ can be considered:

$y_{i t}=\alpha+\left(\beta+\phi z_{i}\right) u_{t}+\gamma s_{i t}+\delta x_{i t}+\left(v_{i}+\eta z_{i}\right)+\varepsilon_{i t}$,

where $u_{\mathrm{t}}$ represents the common observable shock (oil shock). When spending and revenue equations are considered, seemingly unrelated regressions (SUR) estimates are calculated on a jointly considered regression, in order to get more efficient estimates.

\section{The budget authorization and implementation phases appear to be more} relevant than the budget preparation stage. Both panel data regression and nonlinear least squares estimates seem to suggest that the rules and procedures of budget authorization and implementation matter more for fiscal performance than the structures of the budget preparation phase (Table 6 and 7). These results would suggest that particular attention should be given to the institutional settings of the parliamentary budget approval and to the rules for executing and monitoring the approved budget. 
Table 6. Budgetary Institutions (Three Phases) and Fiscal Performance: Evidence from Panel Data Regressions (Fixed Effects)

\begin{tabular}{|c|c|c|c|c|c|c|}
\hline & \multicolumn{6}{|c|}{ Primary Balance } \\
\hline & $(1)$ & (2) & (3) & $(4)$ & $(5)$ & $(6)$ \\
\hline Budget preparation index & $\begin{array}{r}0.39 \\
(1.5)\end{array}$ & $\begin{array}{r}0.6 \\
(1.47)\end{array}$ & & & & \\
\hline Authorization index (budget approval) & & & $\begin{array}{r}1.98 \\
(0.95)^{* *}\end{array}$ & $\begin{array}{r}2.22 \\
(0.89)^{* *}\end{array}$ & & \\
\hline Budget implementation index & & & & & $\begin{array}{r}2.33 \\
(1.47)\end{array}$ & $\begin{array}{r}2.48 \\
(1.44)^{*}\end{array}$ \\
\hline Fragmentation & & $\begin{array}{r}-1.38 \\
(1.66)\end{array}$ & & $\begin{array}{r}-1.99 \\
(1.57)\end{array}$ & & $\begin{array}{r}-1.35 \\
(1.59)\end{array}$ \\
\hline Dummy for EU accession & $\begin{array}{r}-1.54 \\
(0.83)^{*}\end{array}$ & $\begin{array}{r}-1.29 \\
(0.83)\end{array}$ & $\begin{array}{r}-1.63 \\
(0.75)^{* *}\end{array}$ & $\begin{array}{r}-1.28 \\
(0.75)^{*}\end{array}$ & $\begin{array}{r}-1.29 \\
(0.77)^{*}\end{array}$ & $\begin{array}{r}-0.99 \\
(0.78)\end{array}$ \\
\hline Debt -to-GDP ratio (lagged) & $\begin{array}{r}0.08 \\
(0.04)^{*}\end{array}$ & $\begin{array}{r}0.08 \\
(0.04)^{* *}\end{array}$ & $\begin{array}{r}0.07 \\
(0.04)^{*}\end{array}$ & $\begin{array}{r}0.08 \\
(0.03)^{* *}\end{array}$ & $\begin{array}{r}0.07 \\
(0.04)^{*}\end{array}$ & $\begin{array}{r}0.07 \\
(0.03)^{* *}\end{array}$ \\
\hline Unemployment rate & $\begin{array}{r}-0.27 \\
(0.17)\end{array}$ & $\begin{array}{r}-0.29 \\
(0.14)^{* *}\end{array}$ & $\begin{array}{r}-0.35 \\
(0.17)^{* *}\end{array}$ & $\begin{array}{r}-0.31 \\
(0.13)^{* *}\end{array}$ & $\begin{array}{r}-0.29 \\
(0.16)^{*}\end{array}$ & $\begin{array}{r}-0.3 \\
(0.13)^{* *}\end{array}$ \\
\hline Openness index & $\begin{array}{r}3.73 \\
(3.99)\end{array}$ & $\begin{array}{r}4 \\
(3.24)\end{array}$ & $\begin{array}{r}5.2 \\
(3.89)\end{array}$ & $\begin{array}{r}3.76 \\
(3.06)\end{array}$ & $\begin{array}{l}4.21 \\
(3.9)\end{array}$ & $\begin{array}{r}4.21 \\
(3.15)\end{array}$ \\
\hline Dummy for IMF program & $\begin{array}{r}0.03 \\
(0.76)\end{array}$ & & $\begin{array}{r}0.01 \\
(0.71)\end{array}$ & & $\begin{array}{r}0.09 \\
(0.72)\end{array}$ & \\
\hline Output gap & $\begin{array}{r}2.71 \\
(14.99)\end{array}$ & & $\begin{array}{r}-5.71 \\
(14.94)\end{array}$ & & $\begin{array}{r}1.46 \\
(14.66)\end{array}$ & \\
\hline Dummy for election year & $\begin{array}{r}-0.59 \\
(0.58) \\
\end{array}$ & & $\begin{array}{r}-0.4 \\
(0.57) \\
\end{array}$ & & $\begin{array}{r}-0.53 \\
(0.57) \\
\end{array}$ & \\
\hline Observations & 70 & 70 & 70 & 70 & 70 & $\overline{70}$ \\
\hline Number of nid & 10 & 10 & 10 & 10 & 10 & 10 \\
\hline$R$-squared & 0.38 & 0.4 & 0.4 & 0.35 & 0.29 & 0.5 \\
\hline
\end{tabular}

Source: IMF staff estimates.

Notes: Standard errors in parentheses. * significant at $10 \%$;* significant at $5 \%$. Data description and sources in Appendix II.

Table 7. Budgetary Institutions (Three Phases) and Fiscal Performance: Evidence for Nonlinear Least Squares Regressions

\begin{tabular}{|c|c|c|c|}
\hline & \multicolumn{3}{|c|}{ Primary Balance } \\
\hline & $(1)$ & $(2)$ & (3) \\
\hline Budget preparation index & $\begin{array}{r}2.02 \\
(1.78)\end{array}$ & & \\
\hline Authorization index (budget approval) & & $\begin{array}{r}2.86 \\
(0.96)^{* * *}\end{array}$ & \\
\hline Budget implementation index & & & $\begin{array}{r}3.22 \\
(1.59)^{* *}\end{array}$ \\
\hline Electoral rule & $\begin{array}{r}0.29 \\
(0.52)\end{array}$ & $\begin{array}{r}-0.61 \\
(0.63)\end{array}$ & $\begin{array}{r}3.07 \\
(4.37)\end{array}$ \\
\hline Fragmentation & $\begin{array}{r}-1.67 \\
(1.77)\end{array}$ & $\begin{array}{r}-1.73 \\
(1.62)\end{array}$ & $\begin{array}{r}-1.36 \\
(1.7)\end{array}$ \\
\hline Dummy for EU accession & $\begin{array}{r}-0.53 \\
(1.16)\end{array}$ & $\begin{array}{c}-0.82 \\
(0.88)\end{array}$ & $\begin{array}{r}-1.21 \\
(1.1)\end{array}$ \\
\hline Debt -to-GDP ratio (lagged) & $\begin{array}{r}0.09 \\
(0.05)^{*}\end{array}$ & $\begin{array}{r}0.06 \\
(0.04)\end{array}$ & $\begin{array}{r}0.06 \\
(0.05)\end{array}$ \\
\hline Unemployment rate & $\begin{array}{r}-0.25 \\
(0.17)\end{array}$ & $\begin{array}{r}-0.32 \\
(0.14)^{* *}\end{array}$ & $\begin{array}{r}-0.34 \\
(0.15)^{* *}\end{array}$ \\
\hline Openness index & $\begin{array}{r}7.14 \\
(4.32)\end{array}$ & $\begin{array}{r}4.65 \\
(3.73)\end{array}$ & $\begin{array}{r}3.91 \\
(3.46)\end{array}$ \\
\hline Constant & $\begin{array}{r}-12.98 \\
(7.35)^{*} \\
\end{array}$ & $\begin{array}{r}-7.78 \\
(5.01) \\
\end{array}$ & $\begin{array}{r}-10.65 \\
(6.09)^{*} \\
\end{array}$ \\
\hline Observations & 70 & 70 & 70 \\
\hline Number of nid & 10 & 10 & 10 \\
\hline Adj. $R$-squared & 0.53 & 0.59 & 0.56 \\
\hline
\end{tabular}

Source: IMF staff estimates.

Notes: Standard errors in parentheses. * significant at $10 \%$; ** significant at $5 \%$; .*** significant at 1\%. Data description and sources in Appendix II. 


\section{Rules and procedures for budget implementation, in particular, appear to} provide a better fit of actual fiscal performance than the other budget phases. When the fitted values for the primary balance produced by the different estimated regressions are considered, the budget procedures for the implementation phase of the budget appear to provide the best fit of all the phases (Figure 5). Moreover, nonlinear least squares estimates provide a better fit than panel regression estimations.

Figure 5. Hungary: Primary Balance and Fitted Values, 1997-2003
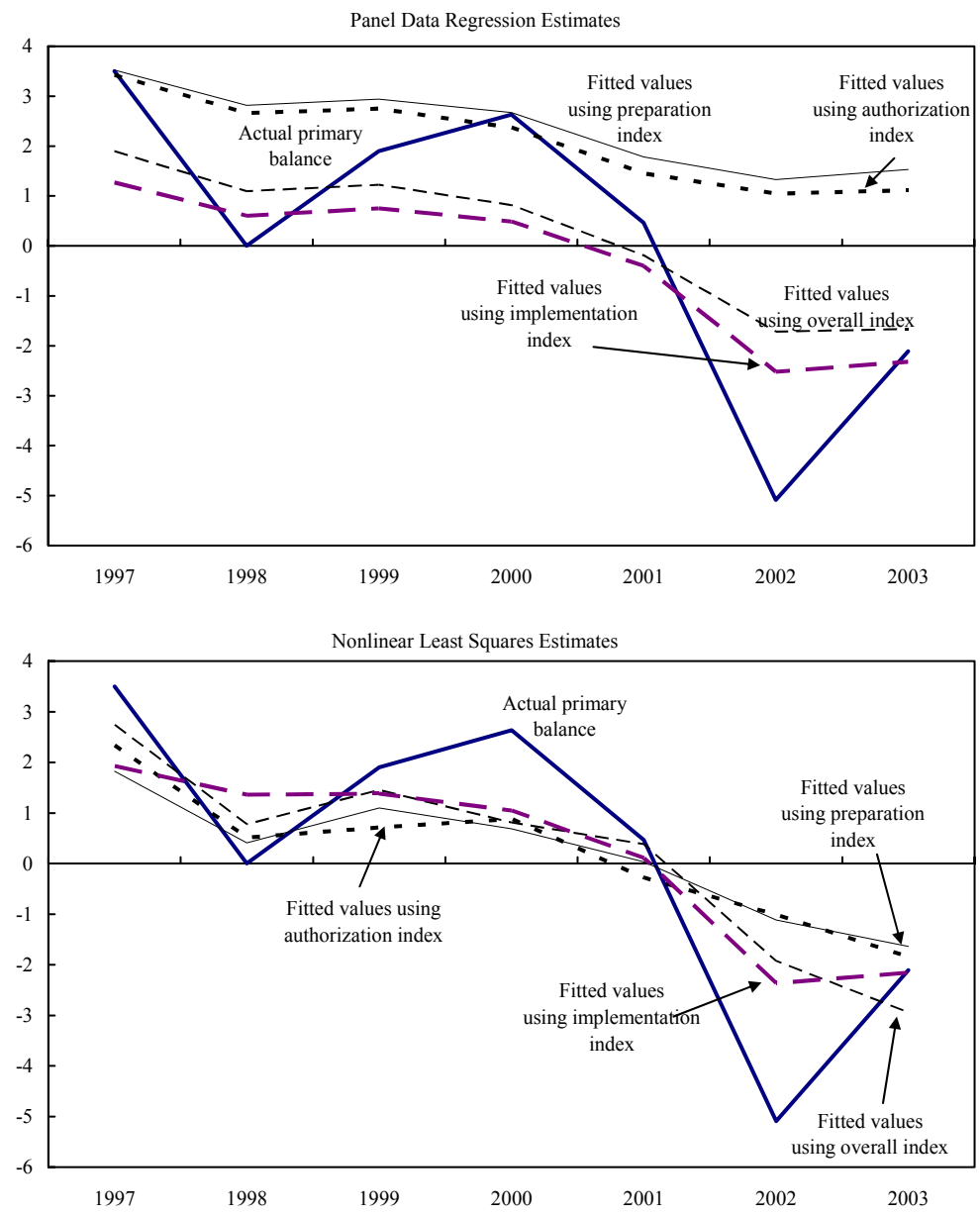

Source: Staff estimates.

45. The preparation for EU accession appears to have had an expansionary effect on fiscal performance. The EU framework, through devices like the Maastricht fiscal limits and the Stability and Growth Pact, is conceived as a mechanism that induces fiscal discipline. However, evidence suggests that the process of preparing for EU accession had an 
expansionary effect on the primary balance position of these countries (although it should be noted that the variable is not always significant across the different representations). ${ }^{12}$ This would be consistent with the fact that these countries had to adjust their fiscal budget to take into account new EU-related expenditures, such as cofinancing of EU funds and administrative upgrades, which eventually placed an extra burden on their fiscal stance.

\section{Fiscal institutions appear to affect fiscal performance through expenditure, but}

do not seem relevant for revenue. In Table 8, expenditure and revenue equations are jointly estimated using the SUR methodology to gain efficiency (Box 1). The results in Table 8 show that fiscal institutions shape expenditure, but they are not relevant for revenue. When the indices for the different phases of the process are considered separately, only the authorization stage appears to be significant. These results should be interpreted with caution, because the data available for revenue and expenditure (from the World Economic Outlook database) are not always consistent with the primary balance data used in the previous analysis (European System of Accounts '95 data from the countries' fiscal notifications to the EC) and are affected by breaks in the series.

Table 8. Budgetary Institutions and Fiscal Performance:

Evidence from Panel Data Regressions (Seemingly Unrelated Regressions Estimates)

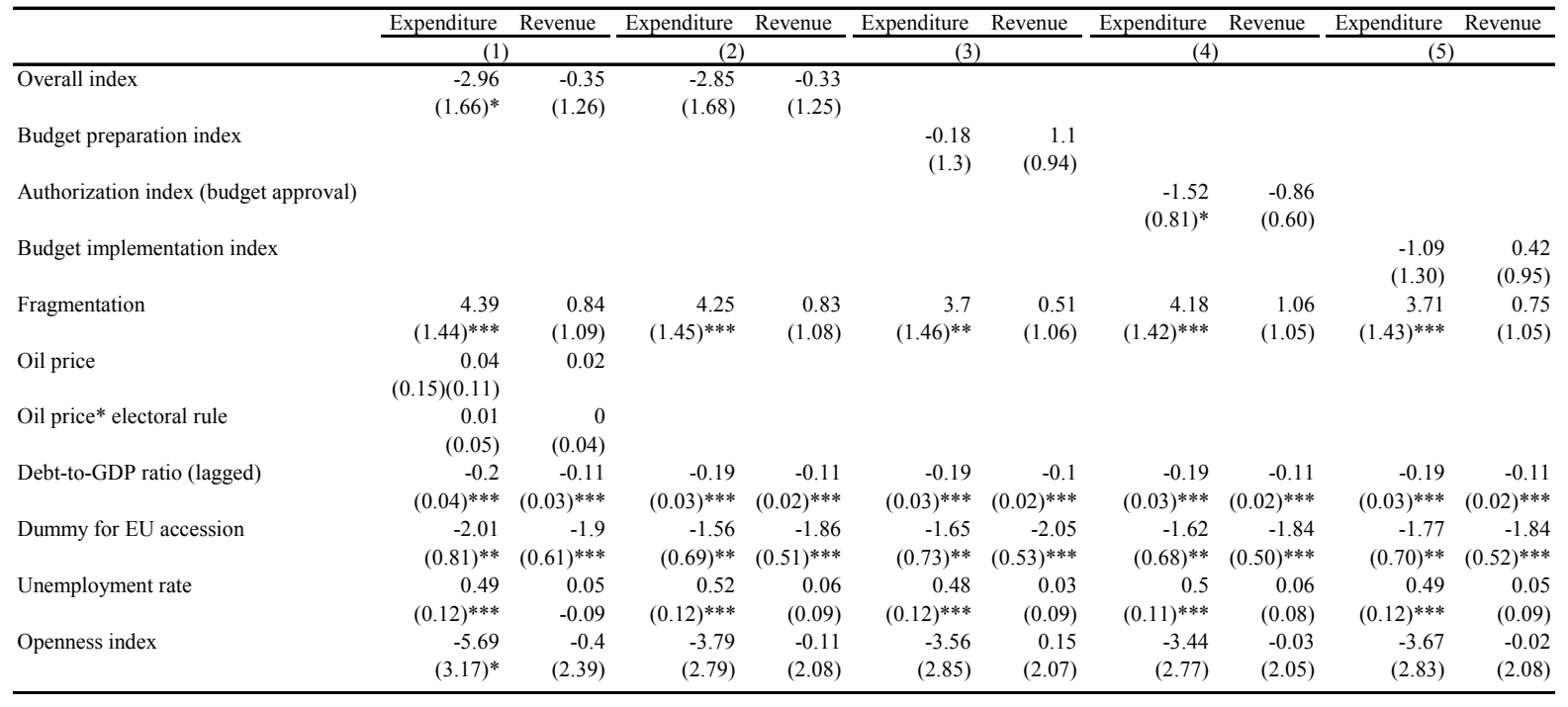

Source: IMF staff estimates.

Notes: Standard errors in parentheses. * significant at 10\%; ** significant at 5\%; ** significant at 1\%. Data description and sources in Appendix II.

47. Government fragmentation also appears to affect expenditure, but not revenue. However, the sign of the latter relationship is the opposite of what one would expect, because more fragmented governments are more affected by the common-pool problem. This

12 To capture the effect of the preparation for EU accession, a dummy is constructed taking value 1 from the year when the country was invited to start the negotiations on aquis communitaire chapters, and 0 before. 
suggests, that less fragmentation would induce more fiscal discipline. In line with the results of this analysis, electoral rules do not appear to matter for fiscal discipline when considered simultaneously with fiscal institutions.

\section{Conclusions}

48. Fiscal institutions are important determinants of fiscal discipline. When the two factors are considered simultaneously, fiscal institutions are highly significant in explaining fiscal discipline, while domestic politics appears less relevant. This result has important positive implications for fiscal discipline, because changing fiscal institutions is usually less troublesome than modifying political institutions, as constitutions are, rightly, not changed often, and the political processes they set in motion have strong inertia.

\section{Important steps to strengthen budget institutions have recently been taken by} the Hungarian authorities. The measures recently introduced in the Public Finances Law, which include stricter rules for the carryover of unused funds from the previous fiscal year and limitations on additional budgetary spending without supplementary appropriations and parliamentary approval, should enhance the quality of budget institutions and help improve fiscal performance.

50. However, further improvements in the quality of fiscal institutions are needed. Regarding the budget preparation phase, the creation of a medium-term fiscal budget framework would help impose fiscal discipline, while achieving greater budgetary transparency and predictability, which are also key for improving fiscal performance (Alesina and Perotti, 1999). In this context, the implementation of a three-year rolling framework, which was under consideration in 2003, that included ceilings on overall expenditure and subceilings on key components, should be reconsidered. Concerning the budget authorization stage, checks should be put in place to ensure that, if additional expenditures are proposed, realistic financing measures are found that do not diminish the likelihood of meeting the fiscal deficits set out in the draft budget (Kiss, Karádi, and Krekó, 2005). Moreover, to improve the rules and procedures of the budget implementation stage, the practice of allowing additional budgetary spending without supplementary appropriations and parliamentary approval should be completely discontinued. Finally, the checks and balances in the expenditure management system could be strengthened, and a more extensive use of scrutiny could be made through the State Audit Office to enhance transparency and credibility. 


\section{REFERENCES}

Alesina, A., and R. Perotti, 1999, "Budget Deficits and Budget Institutions," in Fiscal Institutions and Fiscal Performance, ed. by J. Poterba and J. von Hagen (Chicago: University of Chicago Press.)

Gleich, H., 2003, "Budget Institutions and Fiscal Performance in Central and Eastern European Countries,” European Central Bank, Working Paper No. 215 (Frankfurt, Germany: European Central Bank).

Hallerberg, M., and J. von Hagen, 1999, "Electoral Institutions, Cabinet Negotiations, and Budget Deficits in the European Union" in Fiscal Institutions and Fiscal Performance, ed. by J. Poterba and J. von Hagen (Chicago: University of Chicago Press).

Kiss, G., P. Karádi, and J. Krekó, 2005,“ Structural Challenges Towards the Euro: Fiscal Policy," MNB Background Paper No. 1(Budapest, Hungary: Magyar Nemzeti Bank).

Kontopoulos, Y., and R. Perotti, 1999, "Government Fragmentation, and Fiscal Policy Outcomes: Evidence from OECD Countries," in Fiscal Institutions and Fiscal Performance, ed. by J. Poterba and J. von Hagen (Chicago: University of Chicago Press).

Milesi-Ferretti, G.M., R. Perotti, and M. Rostagno, 2000, "Electoral Systems and Public Spending,” IMF Working Paper 01/22 (Washington: International Monetary Fund).

Persson, T., 2002, “Do Political Institutions Shape Economic Policy?” Econometrica, Vol. 70 (May), pp.883-905.

Persson, T., and G. Tabellini, 1999, "The Size and the Scope of Government: Comparative Politics with Rational Politicians," 1998 Alfred Marshall Lecture, European Economic Review, Vol. 43 (April), pp.699-735.

—, 2000, Political Economics: Explaining Economic Policy, (Cambridge, Massachusetts: MIT Press).

— , 2004, "Constitutional Rules and Fiscal Policy Outcome," American Economic Review, Vol. 94 (March), pp.25-45.

Velasco, A., 1999, “A Model of Endogenous Fiscal Deficits and Delayed Fiscal Reforms,” in Fiscal Institutions and Fiscal Performance, ed. by J. Poterba and J. von Hagen (Chicago: University of Chicago Press).

— 2000, "Debts and Deficits With Fragmented Fiscal Policymaking," Journal of Public Economics, Vol. 76 (April), pp.105-25. 
von Hagen, J., 1998, "Budgeting Institutions for Aggregate Fiscal Discipline," Zentrum für Europäische Integrationsforschung (ZEI) Working Paper B01-1998 (Bonn, Germany: University of Bonn, ZEI).

Von Hagen, J., and I. Harden, 1995, "Budget Processes and Commitment to Fiscal Discipline," European Economic Review, Vol. 39 (April), pp.771-9.

Weingast, B., K. Shepsle, and C. Johnson, 1981, "The Political Economy of Benefits and Costs: A Neoclassical Approach to Distributive Politics," Journal of Political Economy, Hagen and Harden (1995), and Velasco (1999, 2000), Vol. 89, pp. 642-64.

Yläoutinen, S., 2004, "Fiscal Frameworks in the Central and Eastern European Countries," Federal Ministry of Finance Discussion Paper No. 72 (Berlin: Federal Ministry of Finance of Germany). 


\section{CONSTRUCTION OF THE FISCAL INSTITUTIONS INDEX}

\section{This appendix describes the numerical indices constructed to quantify the quality of fiscal institutions.}

\section{A. Overview}

1. Following Gleich (2003), numerical indices were constructed by assigning values (ranging from 0 to 4 ) to the qualitative features of the budget institutions reported in Appendix Table 1, which characterized the three phases of the budget process: preparation, authorization, and implementation. The values have been assigned based on Gleich's survey and updated through information provided in Yläoutinen (2004), fiscal ROSC reports, and through direct contact with the authorities.

2. Budget preparation stage. The institutional features considered are (i) fiscal rules that limit a priori the fiscal deficit; (ii) the establishment of quantitative budget targets based on a macroeconomic framework; and (iii) the relative power of the finance/prime minister in the budget negotiations. The following variables, shown in Appendix Table 1, are taken into consideration during this stage:

- Variable 1 refers to the strictness of permanent constraints on budgetary parameters, such as legal limits on the size of budget deficits or government borrowing.

- Variable 2 assesses control by the finance minister in setting fiscal targets and ceilings to guide the budget preparation.

- Variable 3 captures the power of the finance minister in compiling and negotiating the draft budget.

- $\quad$ Variable 4 reflects how remaining disputes from the bilateral negotiations are reconciled in the executive branch. Procedures in which the whole cabinet is involved are classified as more decentralized than procedures in which senior cabinet committees discussing the matter before it is presented to the whole cabinet.

3. Budget authorization stage. Given the common-pool dilemma, spending and deficit pressures can emerge if legislators are left unconstrained to amend the draft budget proposal. Therefore, institutional regulations that limit the scope of amendments to the budget proposal enhance discipline. The institutional characteristics considered are (i) explicit limits on the scope of amendments; (ii) the sequence of decision making in the authorization process; (iii) the relative power of the executive branch and the parliament; and the role of the president in this process. The four variables considered during the authorization stage follow (Table 1):

- Variable 5 regards formal constraints on the scope for the legislature to amend the government budget, and classifies processes as stricter if the amendments allowed are limited. 
- Variable 6 refers to the sequence of decision making during the budget deliberation, and focuses on whether a decision is made on the size of major budget aggregates before details are worked out.

- Variable 7 summarizes three institutional devices that reflect the strength of the executive branch (the government) vis-à-vis the parliament during the budget deliberation.

- Variable 8 captures the power of the president in the budget process; the less the power, the stronger implicitly the ability of the government in achieving its budget priorities.

4. Budget implementation stage. The first focus at this stage is on how binding the approved budget is. If the government can easily modify budget parameters, the agreements made in the preparation and implementation stages could be undermined and the authorization function of parliament weakened. Also, a degree of flexibility to react to unforeseen revenue shortfalls or spending overruns is necessary at the implementation phase. The variables considered during this stage are the following:

- $\quad$ Variable 9 gets a high score if parliament needs to approve a supplementary budget to institute changes. Similarly, Variable 10 gets a high score if transfers of allocations between ministries requires parliamentary approval. Finally, in Variable 11, the inability to carry over of unused funds to the next year is regarded as conducive to discipline.

- With respect to the flexibility to react to unforeseen shocks, in Variable 12 the finance minister's ability to block expenditures is seen as the best option, with progressive weakening if expenditure blocking requires cabinet approval, parliamentary approval, or no approval at all.

\section{B. Quantification}

Four indices are constructed for each country. Three refer to the quality of budget institutions in the three different stages of the budget process - preparation, authorization, and implementation - and a fourth that represents the overall index. Appendix Table 1 reports the weights used in the aggregation to create the three variables and the overall index. The variables are constructed as follows:

- $\quad$ Budget preparation index $=1 / 4 \sum_{i=1}^{4} x_{i}$

- $\quad$ Budget authorization index $=1 / 4 \sum_{i=5}^{8} x_{i}$ 
- Budget implementation index $=1 / 4 \sum_{i=10}^{13} x_{i}$

The overall index is calculated as the simple average of the three indices above. Appendix Table 2 shows the indices for the countries under consideration. 
Table 1. Construction of the Index: Fiscal Institutions and Their Index Parameters

\begin{tabular}{|c|c|c|c|c|}
\hline & \multicolumn{2}{|c|}{ Weighting factors } & \multirow[b]{2}{*}{ Item } & \multirow[b]{2}{*}{$\begin{array}{c}\text { Numerica } \\
\text { coding }\end{array}$} \\
\hline & Index & $\begin{array}{l}\text { Sub- } \\
\text { index }\end{array}$ & & \\
\hline A. Preparation & 0.33 & & & \\
\hline 1. Existence of statutorily mandated fiscal rules & & 0.25 & & \\
\hline a. Balanced budget rule. & & & & 4.00 \\
\hline b. Limits on public borrowing. & & & & 2.00 \\
\hline c. No legal limits on borrowing. & & & & 0.00 \\
\hline 2. Sequence of budgetary decision making & & 0.25 & & \\
\hline $\begin{array}{l}\text { a. MF sets forth aggregate and specific budget targets in initial budget circular } \\
\text { b. MF proposes, cabinet decides on targets for budget aggregates and spending }\end{array}$ & & & & 4.00 \\
\hline $\begin{array}{l}\text { limits are assigned to each ministry before spending ministries develop } \\
\text { budget requests. }\end{array}$ & & & & 3.00 \\
\hline $\begin{array}{l}\text { c. MF proposes, cabinet decides on targets for budget aggregates before } \\
\text { spending ministries develop budget requests. }\end{array}$ & & & & 2.00 \\
\hline d. Budgetary targets are set on the basis of preliminary budget requests. & & & & 1.00 \\
\hline e. No budget targets are determined. & & & & 0.00 \\
\hline 3. Compilation of the draft budget & & 0.25 & & \\
\hline a. Finance ministry holds bilateral negotiations with each spending ministry. & & & & 4.00 \\
\hline b. Finance ministry holds bilateral negotiations, other parties included. & & & & 2.00 \\
\hline $\begin{array}{l}\text { c. Finance ministry only collects budget requests and compiles summary for } \\
\text { cabinet session. }\end{array}$ & & & & 0.00 \\
\hline 4. Members of executive responsible for reconciling conflicts over budget bids & & 0.25 & & \\
\hline a. MF or PM can veto or overrule cabinet decision. & & & & 4.00 \\
\hline b. Senior cabinet committee, then whole council of ministers or cabinet. & & & & 2.00 \\
\hline c. Executive collectively (e.g., council of ministers or cabinet). & & & & 0.00 \\
\hline \multicolumn{5}{|l|}{ B. Legislation } \\
\hline 5. Constraints on the legislature to amend the government's draft budget & & 0.25 & & \\
\hline $\begin{array}{l}\text { a. Deficit provided in the draft budget cannot be exceeded, or } \\
\text { individual amendments have to indicate offsetting changes. }\end{array}$ & & & & 4.00 \\
\hline b. No restrictions. & & & & 0.00 \\
\hline 6. Sequence of votes & & 0.25 & & \\
\hline a. Initial vote on total budget revenues, expenditures, and the deficit. & & & & 4.00 \\
\hline b. Final vote on budget aggregates. & & & & 0.00 \\
\hline 7. Relative power of the executive vis-à-vis the parliament & & 0.25 & & \\
\hline a. Cabinet can combine a vote of confidence with a vote on the budget. & & & 0.33 & 4.00 \\
\hline $\begin{array}{l}\text { b. Draft budget is executed if parliament fails to adopt the budget before the } \\
\text { start of the fiscal year. }\end{array}$ & & & 0.33 & 4.00 \\
\hline c. Parliament can be dissolved if it fails to adopt the budget in due time. & & & 0.33 & 4.00 \\
\hline 8. Authority of the national president in the budget procedure & & 0.25 & & \\
\hline a. No special authority. & & & & 4.00 \\
\hline b. President has veto right (president elected by parliament). & & & & 2.67 \\
\hline c. President has veto right (president directly elected by citizens). & & & & 1.33 \\
\hline d. President has veto right (qualified majority required to override veto). & & & & 0.00 \\
\hline C. Implementation & 0.33 & & & \\
\hline 9. Flexibility to change budget aggregates during execution. & & 0.25 & & \\
\hline $\begin{array}{l}\text { a. Any increase in total revenues, expenditures and the deficit needs to be } \\
\text { approved by parliament in a supplementary budget. }\end{array}$ & & & & 4.00 \\
\hline $\begin{array}{l}\text { b. Revenue windfalls can be used to increase expenditure without the approval } \\
\text { of parliament as long as the deficit is not increased. }\end{array}$ & & & & 2.67 \\
\hline c. Simultaneous changes in revenue and expenditures allowed without & & & & \\
\hline approval of parliament if budget balance is not changed. & & & & 1.33 \\
\hline d. At total or large discretion of government. & & & & 0.00 \\
\hline 10. Transfers of expenditures between chapters (i.e. ministries' budgets) & & 0.25 & & \\
\hline a. Require approval of parliament. & & & & 4.00 \\
\hline b. FM or cabinet can authorize transfers between chapters. & & & & 2.67 \\
\hline c. Limited. & & & & 1.33 \\
\hline d. Unrestricted. & & & & \\
\hline 11. Carryover of unused funds to next fiscal year & & 0.25 & & \\
\hline a. Not permitted. & & & & 4.00 \\
\hline b. Only if provided for in initial budget or with finance ministry approval. & & & & 2.67 \\
\hline c. Limited. & & & & 1.33 \\
\hline d. Unlimited. & & & & 0.00 \\
\hline 12. Procedure to react to a deterioration of the budget deficit (due to unforeseen & & & & \\
\hline revenue shortfalls or expenditure increase) & & 0.25 & & \\
\hline a. MF can block expenditures. & & & & 4.00 \\
\hline b. The cabinet can block expenditures. & & & & 2.67 \\
\hline c. Approval of the parliament necessary to block expenditures. & & & & 1.33 \\
\hline d. No action is taken. & & & & 0.00 \\
\hline
\end{tabular}




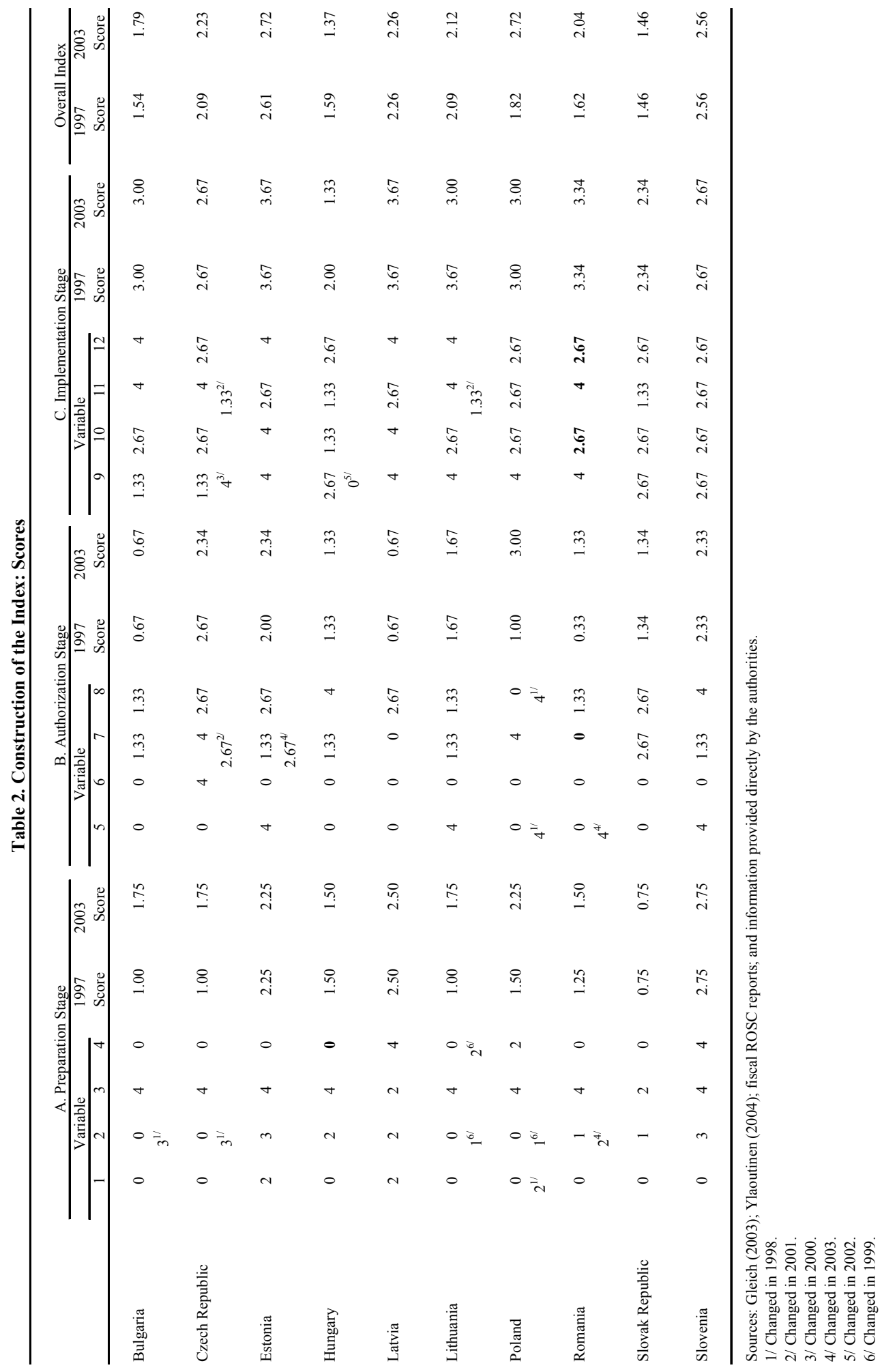




\section{DATA DESCRIPTION AND SOURCES}

The following variables were used in the analysis.

\section{Dependent variables}

1. For the fiscal outcome, the general government primary balance is considered. Data from the fiscal notifications to the European Commission were used. Total revenue and grants and total expenditure and net lending minus interest payments are also considered in the analysis. Since these data are not available for all countries in the sample from the fiscal notifications, data from the IMF World Economic Outlook (WEO) database are used.

\section{Explanatory variables}

2. Fiscal institutions indices. These variables are described in Appendix I. The sources are: Gleich (2003), Yläoutinen (2004), fiscal ROSC reports, and direct information from the authorities.

3. Political institutions variables. Two variables are considered. Following Persson and Tabellini (1999), the mean district magnitude is used to define electoral rules. The logarithm of this variable is used in the analysis. Government fragmentation is also considered. This variable is constructed as the Herfindhal index, ranging from 0 to 1 , with higher values indicating smaller coalitions. Data sources are the following:

Database on Political Institutions, 2000 (updated in 2004), prepared by P. Keefer; available via the internet http://www.worldbank.org/research/bios/pkeefer.htm;

Parties and Elections in Europe; available via the internet www.parties-and-elections.de; and Economist Intelligence Unit reports.

4. Other control variables. The other variables considered (data source: IMF WEO) are debt in percent of GDP (lagged); a dummy for an IMF program, taking value 1 if the country had a program with the Fund during that year, 0 otherwise; the unemployment rate; the index of openness (imports plus exports normalized by GDP); the output gap, applying the Hodrick-Prescott filter to GDP data; a dummy assuming a value of 1 for the year of elections, 0 otherwise; and a dummy for the preparation to EU accession, taking a value of 1 from the year the country was invited to start the negotiations on aquis communitaire chapters. 


\section{Inflation Persistence And Monetary Policy ${ }^{13}$}

\section{A. Introduction}

\section{Hungarian inflation declined from 10.5 percent in 2001 to 3.5 percent by early}

2005. However, inflation is still high based on a number of benchmarks and the recent gains could be reversed. First, inflation is still above the low rates enjoyed by other Central European countries (CECs) such as Poland and the Czech Republic (Figure 1). Second, inflation was above the Maastricht criterion of 2.4 percent in 2004. Third, inflation is above the Magyar Nemzeti Bank's (MNB's) own estimate of the optimal inflation rate of 2.3-3.2 percent. $^{14}$

Figure 1. Inflation in Hungary and Selected CECs, 1997-2005

(In percent)
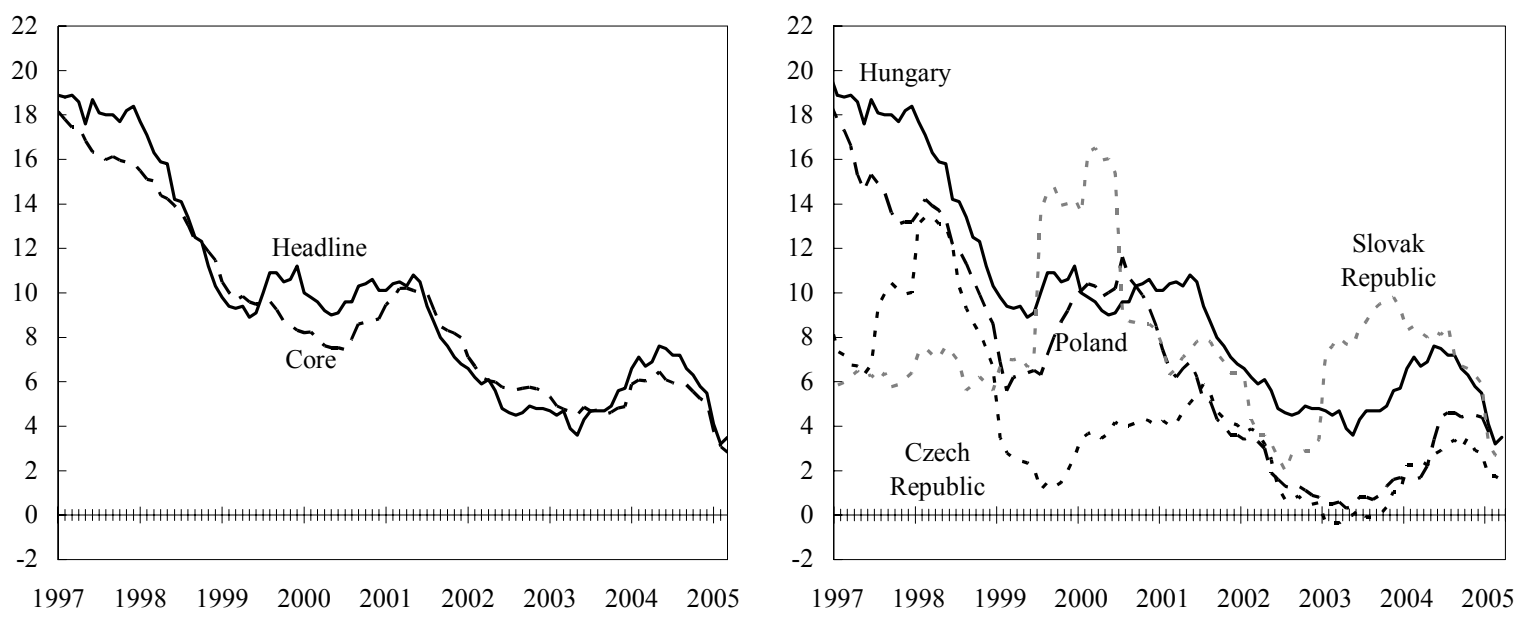

52. In part, Hungary has benefited from the worldwide disinflationary environment associated with globalization. As Rogoff (2003) notes, global inflation has declined dramatically from 30 percent to 4 percent over the past ten years and a large part of this change can be attributed to the increased level of competition in product and labor markets that has resulted from globalization. In Hungary's case, competition has been stepped up following accession to the European Union, as the MNB's Quarterly Report on Inflation of February 2005 concludes.

53. This chapter focuses on two questions related to Hungary's recent disinflation.

First, how persistent has inflation been? Second, what factors have influenced the conduct of

${ }^{13}$ Prepared by Daniel Leigh. The paper has greatly benefited from comments by Abdul Abiad, Leo Bonato, Oya Celasun, Stefania Fabrizio, Zoltán Jakab, Douglas Laxton, and Ashoka Mody.

${ }^{14}$ See Kiss and Krekó (2004) for estimates of the optimal rate of inflation in Hungary. 
monetary policy since the introduction of inflation targeting in 2001? Addressing these two questions could be part of a broader analysis of Hungarian inflation.

54. The degree of inflation persistence is important because it plays a role in determining the speed of disinflation and the associated output costs. ${ }^{15}$ Inflation persistence refers to the tendency of inflation to converge slowly toward its long-run value following various shocks, such as oil price or indirect tax shocks. Other things equal, the more forward-looking agents are, the faster actual and expected inflation will decline to the targeted level. By contrast, if agents' price-setting behavior is backward looking because of wage and price indexation or adaptive expectations, a rapid disinflation will incur large output losses. For this reason, it is important to assess how "inertial" the inflation process is.

55. Because inflation is ultimately a monetary phenomenon, an investigation into the recent conduct of monetary policy is warranted. To this end, a monetary policy reaction function is estimated for Hungary for the period covering inflation targeting (IT) begun in 2001. The analysis permits a decomposition of interest rate changes into policy responses to the inflation forecast and to other variables, such as the exchange rate.

56. The main findings are as follows. First, the analysis reveals a significant forward-looking component in Hungarian inflation, implying that inflation persistence is relatively low. This finding, in part, helps to explain why Hungarian inflation declined rapidly following the 2004 inflation shocks. Second, while monetary policy decisions have appropriately responded to the inflation forecast, exchange rate-stabilizing considerations have also played a role that has not always been consistent with the objective of directly lowering the rate of inflation.

57. The remainder of this chapter is structured as follows. Section B conducts an analysis of inflation persistence in Hungary. Section C analyzes the MNB's monetary policy since the beginning of inflation targeting in 2001. Section D concludes.

\section{B. Inflation Persistence in Hungary}

58. The analysis of inflation is based on three approaches: (i) a univariate analysis; (ii) an estimation of the relative importance of forward- and backward-looking price-setting behavior; and (iii) an analysis of the persistence of household inflation expectations.

\section{A univariate analysis}

59. A univariate analysis of inflation dynamics is used to assess inflation persistence both in relative and absolute terms. First, a simple regression of monthly seasonally adjusted consumer price inflation on its lag and on a linear trend is estimated, as in equation

${ }^{15}$ For a discussion of the output costs associated with disinflation, see, for example, Ball (1995), or Buiter and Grafe (2001). 
(1), where $\pi_{t}^{m}=\frac{P_{t}}{P_{t-1}}-1$ and $P_{t}$ is the seasonally adjusted consumer price index (CPI) in month $t:^{16}$

$\pi_{t}^{m}=\alpha t+\beta \pi_{t-1}^{m}+\varepsilon_{t}$.

A higher value of $\beta$ indicates stronger inflation persistence. The estimate of $\beta$ can be used to compute an estimate of the half-life of a unit shock to inflation. The half-life measures the length of time needed to halve the magnitude of the original shock and is obtained using the formula in equation (2):

half life $=\left|\frac{\ln \left(\frac{1}{2}\right)}{\ln (\beta)}\right|$.

To allow for time variation in the degree of persistence, the half-life is estimated recursively using rolling samples of 60 monthly observations from January 1994 to March 2005. The procedure is also repeated using CPI inflation data for Poland and the Czech Republic. ${ }^{17}$ The results are displayed in Figure 2, where the horizontal axis indicates the end of the regression window.

60. The results in Figure 2 suggest that CPI inflation persistence in Hungary is small in absolute terms and lower than in Poland. The estimated half-life of a unit shock to CPI inflation in Hungary is only about one month and has declined somewhat since 1999. As Figure 2 suggests, CPI inflation in Hungary is also less persistent than in Poland, where the estimated half life has been in the 1.5-2.5 month range since 2000. In the Czech Republic, inflation inertia appears to be even lower than in Hungary, with a half life of less than one month. For further comparison, Celasun, Gelos, and Prati (2003) apply a similar method to Turkish CPI data and obtain a half-life of about one month in Turkey over the 1999 to 2002 period. ${ }^{18}$

${ }^{16}$ The X12 procedure is used to adjust the CPI data for seasonal patterns.

${ }^{17}$ Stock (2001), in a comment on Cogley and Sargent (2001), notes: "There are a variety of ways to measure persistence, none perfect." He then goes on to use an esimation method similar to the one employed here.

${ }^{18}$ Using an alternative seasonal adjustment procedure to adjust the CPI of the three countries, such as TRAMO/SEATS, yields a smoother path for SA inflation. Consequently, with TRAMO/SEATS, the measured half-lives of CPI inflation in all three countries are higher, but their relative sizes remain unchanged. Similarly, if a smoother measure of inflation, such as core CPI inflation is used, the measured half-lives in all three countries are higher, but their relative sizes remain unchanged. 
Figure 2. Inflation Persistence in Hungary, Poland, and the Czech Republic, 1999-2005

(Estimates of the half-life of a unit shock, months, in percent)
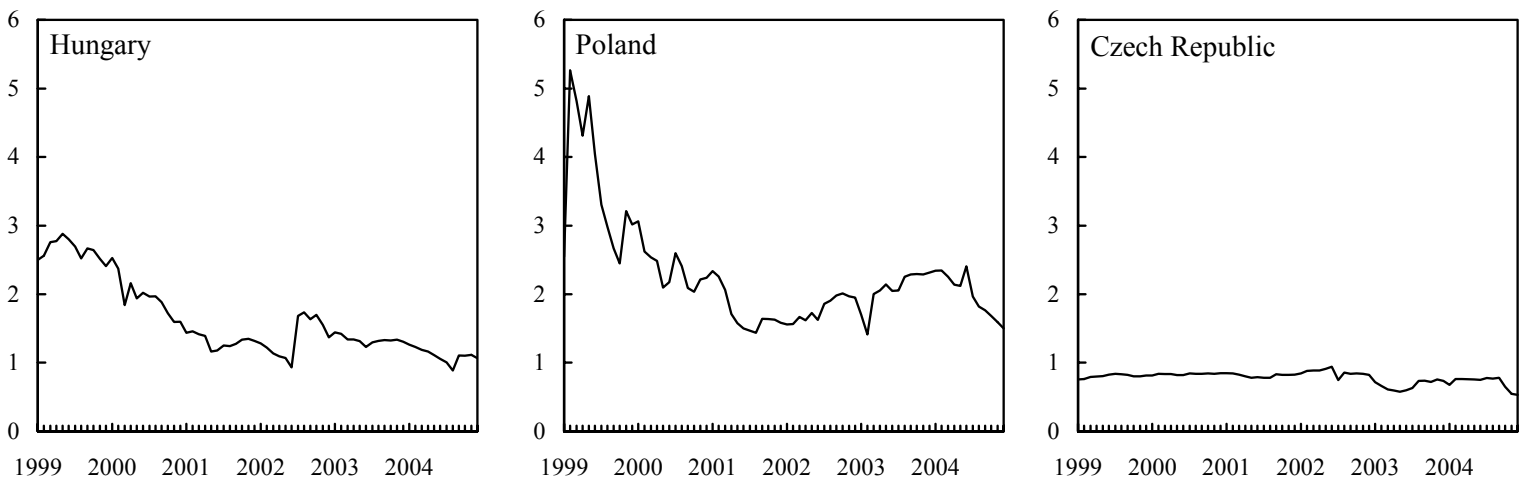

The relative importance of backward- versus forward-looking behavior

61. The second approach assesses the relative importance of backward- and forward-looking behavior by estimating a multivariate regression that nests both hypotheses. The distinction between backward- and forward-looking behavior is important from a policy point of view because the output costs of a disinflation are, other things equal, higher with backward-looking behavior. In this section, after describing the empirical model, survey inflation forecasts are used to assess the degree of forward-looking pricing behavior in Hungary. The results suggest that expectations of future inflation play a much more important role than past inflation in explaining current inflation dynamics.

\section{The empirical model}

62. In the model, inflation depends linearly on the previous period's inflation rate, on the one-period-ahead expected inflation rate, and on the current marginal cost. ${ }^{19}$ The empirical model thus nests the possibility of both backward- and forward-looking price-setting behavior, as in Galí and Gertler (1999), and is a modification of the Calvo (1983) New Keynesian Phillips Curve in which all agents are forward looking. The inflation process is described by

$\pi_{t}=\alpha E_{t} \pi_{t+1}+(1-\alpha) \pi_{t-1}+\beta m c_{t}+\varepsilon_{t}$

The dependent variable, $\pi_{t}$, is the 12-month inflation rate at the end of a given month, $E_{t} \pi_{t+1}$ is expected inflation for the following 12 months, and lagged inflation refers to the period between 12 and 24 months ago. Real marginal cost, $m c_{t}$, is the 12-month average over the past 12 months. Since a typical firm in a small open economy is likely to use imported intermediate goods and domestic labor as inputs in production, real marginal cost, $m c_{t}$, is proxied with a combination of the real effective exchange rate (the ratio of the trade

${ }^{19}$ For applications of this specification on a number of other emerging markets, see Celasun, Gelos, and Prati (2004). 
share-weighted average of foreign consumer price levels to the domestic price level, which is a proxy of the real cost of imported inputs), and domestic real unit labor costs (both in deviation from trend). ${ }^{20}$ An increase the real exchange rate therefore signals a depreciation. The estimated equation is thus:

$\pi_{t}=\alpha E_{t} \pi_{t+1}+(1-\alpha) \pi_{t-1}+\beta R E E R_{t}+\gamma R U L C_{t}+\varepsilon_{t}$

where $R E E R$ is the detrended real effected exchange rate and $R U L C$ is the detrended real unit labor cost. The degree of inflation inertia is governed by the parameter $(1-\alpha)$. The higher is the share of backward-looking price setters, the larger is the weight $(1-\alpha)$ on the lagged inflation term. $^{21}$

63. Inflation expectations are measured using actual surveys of inflation forecasts made by professional forecasters. The forecasts are collected by Reuters on a monthly basis since 1997, for the end of the current year and of the following year. A 12-month-ahead expected inflation measure can then be obtained by taking the weighted average of the forecasts for the current and following year. In December, for instance, the one-year-ahead inflation forecast is simply the forecast for the next year. In January, a weight of eleven-twelfths is attached to the forecast of the current year, and one-twelfth to the forecast of the next year, and so on.

64. As Figure 3 suggests, expectations track the actual realized inflation rates closely. Figure 3 presents a graph of actual inflation over the last 12 months against one-year-ahead forecasts made 12 months before. An important question is whether the survey expectations contain information about future inflation that is not contained in past inflation. To answer this question, actual inflation is regressed on the forecast made one year earlier and on the inflation rate on year earlier. The results (not shown) suggest that survey expectations have statistically significant forecasting power for future inflation, even after controlling for the inflation rates of recent history. In this sense, the survey expectations are forward-looking. ${ }^{22}$

${ }^{20}$ The trend is computed using the Hodrick-Prescott filter with a smoothing parameter of 14,400 , a standard magnitude for data at the monthly frequency.

${ }^{21}$ The level of excess demand, measured by the output gap, is often used as a proxy for real marginal cost in the literature (see, for example, Fuhrer and Moore, 1995). However, as Gali and Gertler (1999) argue, real unit labor costs are a better proxy for marginal cost since the output gap is likely to be measured with considerable uncertainty.

${ }^{22}$ For further tests of forecast accuracy related to the Reuters poll, see Krekó and Vonnák (2003). 


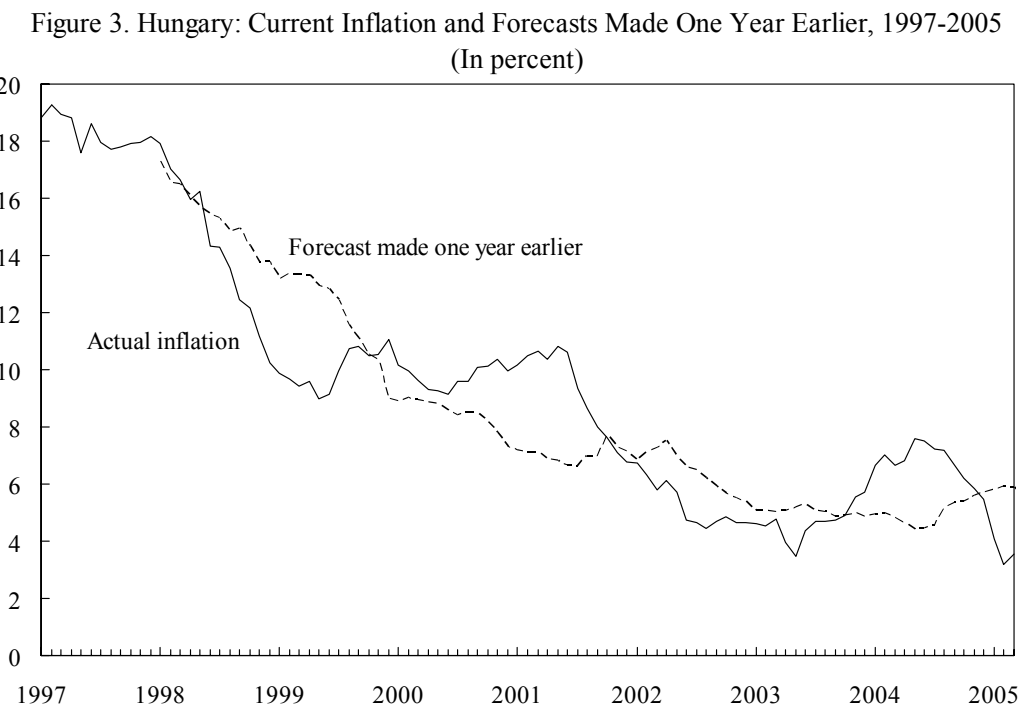

\section{Results}

65. Table 1 displays the estimates of equation (4) based on three estimation approaches. The first column displays the results obtained using ordinary least squares (OLS). The second column reports results obtained using instrumental variables (IV). The IV regression addresses the possible endogeneity of real exchange rate and average real unit labor costs to the unobservable disturbance to inflation in the current period. The instruments are the 12-month lagged inflation rate, expected one-year-ahead inflation, and 12-month lags of the real exchange rate and of the real unit labor costs. The final column reports results obtained using the same instrumental variables but with an alternative measure of expected inflation: actual future inflation. Actual future inflation is often used as a proxy for expected inflation in the literature, although it implicitly imparts greater forecast accuracy to agents than may seem plausible. ${ }^{23}$

\section{In all three cases, expected future inflation plays a larger role than lagged} inflation in determining current inflation. The point estimate of $\alpha$, the weight on future expected inflation is larger than one-half in all three cases. In the first two columns, the weight is significantly larger than one-half at the 1 percent level, as shown by the $p$-values in the second-to-last row. The finding of forward-looking behavior is intuitive given the very limited extent of price and wage indexation to past inflation in Hungary. The finding of a substantial forward-looking component in inflation is also consistent with the findings of Celasun, Gelos and Prati (2004) who estimate a very similar model using data on ten

\footnotetext{
${ }^{23}$ For example, Galí and Gertler (1999) use actual future inflation as a proxy for expected inflation and estimate the New Keynesian Phillips Curve using general method of moments.
} 
emerging markets. ${ }^{24}$ Finally, the results are robust to excluding the admittedly imprecise real marginal cost proxies from the equation. A regression of actual inflation on past inflation and expected inflation yields an even larger weight on expected inflation.

Table 1. Hungary: Estimates of Forward- Versus Backward-Looking Behavior 1/

\begin{tabular}{lccc}
\hline \hline Estimation Technique & OLS & IV & IV \\
Measure of expectations & Survey expectations & Survey expectations & Actual future inflation \\
\hline Expected future inflation & 0.71 & 0.74 & 0.61 \\
& $(0.07)$ & $(0.08)$ & $(0.14)$ \\
Lagged inflation & 0.29 & 0.26 & 0.39 \\
& $(0.07)$ & $(0.08)$ & $(0.14)$ \\
Real exchange rate gap & 0.23 & 0.24 & 0.15 \\
& $(0.08)$ & $(0.08)$ & $(0.10)$ \\
Real unit labor costs gap & 0.05 & 0.05 & 0.04 \\
& $(0.26)$ & $(0.33)$ & $(0.49)$ \\
$p$-value of test: $\alpha=0.5$ & 0.004 & 0.008 & 0.415 \\
$R^{2}$ & 0.92 & 0.85 & 0.67 \\
\hline \hline
\end{tabular}

1/ All standard errors are corrected for heteroscedasticity and serial correlation using a Newey-West procedure.

\section{Estimating the Persistence of Household Inflation Expectations}

67. The third approach analyzes the degree of persistence in household expectations. This approach complements the second by analyzing what determines expectations of future inflation and how quickly typical consumers absorb information about the inflation outlook. The importance of household inflation expectations arises from their influence on wage aspirations, and on consumption and savings decisions. The degree of inertia in household expectations, therefore, also influences the persistence of inflation shocks and the costs of disinflation. The model's estimates suggest that, although household expectations are "sticky," they are less persistent than in the United States.

68. The methodology used in this approach draws on the Carroll (2003) model, in which households' views derive from news reports of the views of professional forecasters, which represent the most up-to-date predictions of future inflation. The model is based on the assumption that consumers update information sporadically rather than instantaneously. Each period, a fraction $\alpha$ of consumers update their inflation forecasts using the most up-to-date (professional) inflation forecasts published in the news media. The

${ }^{24}$ The finding of a strongly forward-looking component does not necessarily indicate high credibility of the authorities' disinflation strategy. A large weight on expected inflation has also been found in the case of Turkey when inflation was high and variable (see Celasun, Gelos, and Prati (2004), for instance). If credibility is very low and inflation is high and variable, it may be costly to make pricing decisions based on past movements in prices. 
remaining (1- $\alpha$ ) fraction of consumers' views about future inflation are based on outdated information collected in the past.

69. This model implies the following specification for observed household inflation expectations. ${ }^{25}$ Household expectations for the next year are a weighted average of the current up-to-date (professional) inflation forecast and last period's measured inflation expectations:

$H_{t}\left(\pi_{t, t+12}\right)=\alpha P_{t}\left(\pi_{t, t+12}\right)+(1-\alpha) H_{t-1}\left(\pi_{t-1, t+11}\right)$,

where $H_{t}\left(\pi_{t, t+12}\right)$ is the mean measured household $(H)$ expectation of 12-month inflation in period $t+12$, made in period $t ; H_{t-1}\left(\pi_{t-1, t+11}\right)$ is the mean measured household expectation of 12-month inflation in period $t+11$ made in period $t$ - 1 ; and $P_{t}\left(\pi_{t, t+12}\right)$ is the professional $(P)$ forecast of 12-month inflation in period $t+12$.

70. Estimating equation (4) requires a source of professional inflation expectations, and of household inflation expectations. For consumer expectations, the European Commission (EC) publishes a survey on consumer expectations in Hungary, the GKI survey, on a monthly frequency, going back to 1993. Unfortunately, however, the EC survey does not ask households to name a specific figure for the future inflation rate. Rather, households are asked whether, compared with the previous 12 months, they expect prices over the next 12 months to (i) rise more rapidly, (ii) rise at the same rate, (iii) rise at a slower rate, (iv) stay about the same, or (v) fall. ${ }^{26}$ The survey is then summarized by a "balance statistic," an index that rises when agents expect inflation to accelerate over the coming year. This index can then be converted into a forecast of the change in the inflation rate by using the predicted value from a regression of the actual change in inflation on the predicted change. ${ }^{27}$ Thus, the regression

$$
\bar{\pi}_{t, t+12}-\bar{\pi}_{t-12, t}=\gamma_{0}+\gamma_{1} G K I_{t}
$$

is estimated, where $\bar{\pi}_{t-12, t}$ is the average (year-on-year) inflation rate over the next 12 months, that is, $\pi_{t-12, t}^{-}=\frac{1}{12} \sum_{i=0}^{11} \pi_{t-i}$, and $G K I_{t}$ is the balance statistic for future inflation based on the survey made in month $t$. The fitted values from equation (5) are then deployed to

${ }^{25}$ For a full, microfounded derivation of this equation, see Carroll (2003).

${ }^{26}$ The households can also respond that they do not have a view on future inflation.

${ }^{27}$ Carroll (2003) uses this method to convert a similar index, the Michigan diffusion index of household unemployment expectations, into a quantitative forecast. An alternative measure of household expectations, the Tarki quantitative survey, is available only on a quarterly frequency, starting in May 2002 (11 observations to date). 
construct the quantitative household expectation series, $H_{t}\left(\pi_{t, t+12}\right){ }^{28}$ Professional inflation forecasts for average inflation have been available from the Reuters poll since 1997.

71. Table 2 presents the estimates of the household expectations model and suggests that, in a given month, about 20 percent of households access the latest available inflation forecast. The estimate is robust to three alternative specifications (Table 2). For comparison, in the United States, the proportion is about 8 percent (Carroll, 2003). The findings presented here therefore suggest that, although Hungarian household expectations are "sticky" and do not all adjust instantly, Hungarian consumers do receive information about inflation more frequently than do consumers in the United States. This finding is intuitive. In a country with higher and more variable inflation, inflation is likely to affect households more and feature more prominently in the news media than in a country with low and stable inflation, such as the United States. The second row of Table 2 shows that the model's hypothesis that the coefficients on professional and household expectations sum to one on the right-hand side of Equation (4) has a $p$-value of 18 percent. The data, therefore, fail to reject the model's unit sum assumption. The final row of Table 2 reports that the results are robust to including a constant and a lagged inflation term in the model. Both additional terms are small and statistically insignificant at the 10 percent level.

Table 2. Hungary: Estimates of Speed of Updating of Household Expectations 1/

Estimating Equation: $H_{\mathrm{t}}\left(\bar{\pi}_{\mathrm{t}, \mathrm{t}+12}\right)=\alpha_{0}+\alpha_{1} P_{\mathrm{t}}\left(\bar{\pi}_{\mathrm{t}, \mathrm{t}+12}\right)+\alpha_{2} H_{\mathrm{t}-1}\left(\bar{\pi}_{\mathrm{t}-1, \mathrm{t}+11}\right)+\alpha_{3} \bar{\pi}_{\mathrm{t}-13, \mathrm{t}-1}+\varepsilon_{\mathrm{t}}$

\begin{tabular}{cccccccc}
\hline \hline & & & & & & & Test \\
Equation & $\alpha_{0}$ & $\alpha_{1}$ & $\alpha_{2}$ & $\alpha_{3}$ & $R^{2}$ & DW & $p$-value \\
\hline 1 & & 0.21 & 0.79 & & 0.95 & 1.97 & $\alpha l=0$ \\
& & $(0.05)$ & $(0.05)$ & & & & 0.00 \\
2 & & 0.17 & 0.82 & & 0.95 & 2.07 & $\alpha 1+\alpha 2=1$ \\
& & $(0.06)$ & $(0.06)$ & & & & 0.18 \\
3 & 0.23 & 0.23 & 0.82 & -0.07 & 0.95 & 2.12 & $\alpha 3=0$ \\
& $(0.19)$ & $(0.09)$ & $(0.05)$ & $(0.05)$ & & & 0.18 \\
\hline \hline
\end{tabular}

1/ All standard errors are corrected for heteroscedasticity and serial correlation using a Newey-West procedure.

\section{The Conduct of Monetary Policy}

72. To analyze the recent conduct of monetary policy, a monetary policy reaction function is estimated. The analysis permits a decomposition of interest rate changes into

${ }^{28}$ Intuitively, a separate "horse race" regression (not reported here) of actual inflation on the household expectation series and on the professional forecast series reveals that professional forecasts have a much stronger forecasting power than do the household expectations. So, although household expectations appear to have some forecasting power, professional forecasters know a lot more than households do. 
policy responses to the inflation forecast and to other variables, such as the exchange rate. The sample of analysis covers the IT period, begun in 2001.

73. IT was introduced in May 2001 and the MNB's primary objective was defined as the achievement and maintenance of price stability. ${ }^{29}$ The MNB committed itself to "implementing a gradual, but firm disinflation program over the course of several years," (MNB, August 2001 Quarterly Report on Inflation) by achieving a series of declining inflation targets. Each inflation target was expressed as a central target for the 12-month change in the CPI in December, with \pm 1 percent tolerance band, announced at least six quarters ahead. Figure 4 shows the series of inflation targets that have been announced since 2001, along with actual inflation. The targets were met in 2001 and 2002, but were missed in 2003 and 2004.

Figure 4. Hungary: Realized Versus Target Inflation, 2001-2006

(In percent)

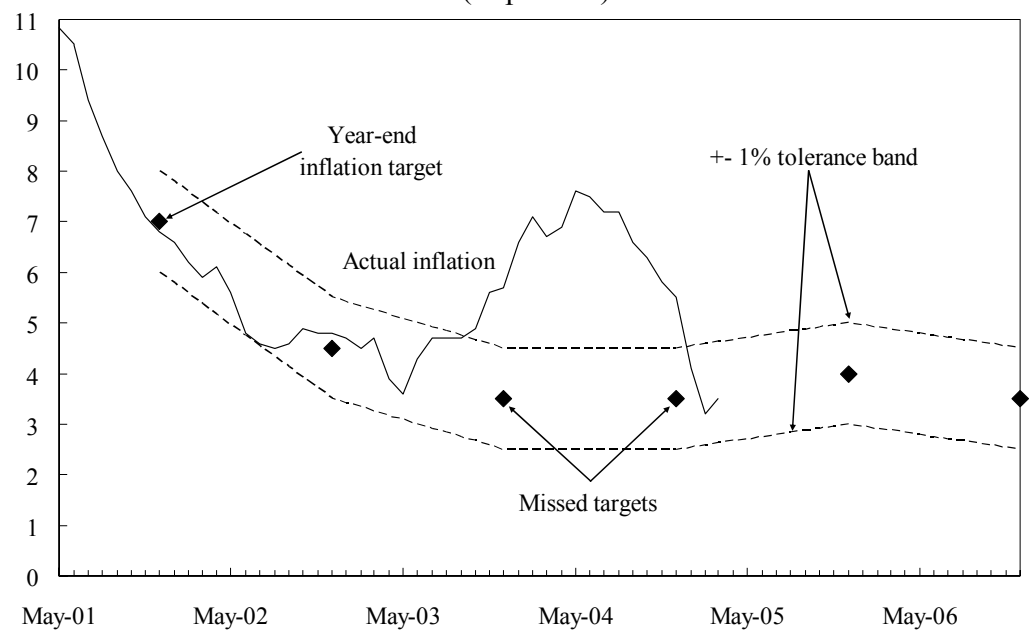

74. In addition to meeting the inflation targets, the MNB has the obligation of keeping the exchange rate in the band. At the time of the introduction of IT, the exchange rate band in which the forint is allowed to fluctuate against the euro was widened to \pm 15 percent around a central parity rate. Figure 5 shows the exchange rate band, along with the actual exchange rate. The exchange rate has been in the strong half of the band since the introduction of IT, fluctuating around a mean of Ft 250 per euro.

\footnotetext{
${ }^{29}$ For further details on the MNB's legal mandate under the Central Bank Act, see, for instance, the MNB Press Release of June 12, 2001.
} 


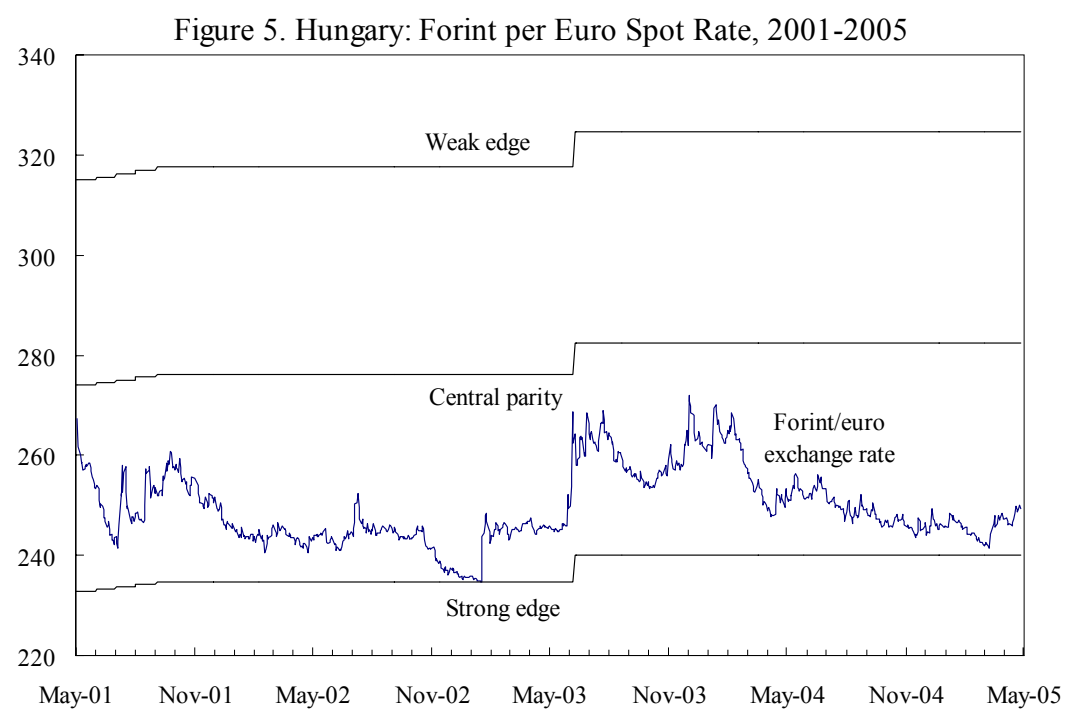

\section{Methodology}

75. The estimated monetary policy reaction function used in this section is based on the standard approach in the monetary policy literature, as exemplified by Clarida, Galí, and Gertler (1998). The policy interest rate reacts to deviations of expected inflation and the exchange rate from their respective targets. Specifically, the desired interest rate, $i_{t}^{*}$, is determined by

$i_{t}^{*}=\bar{r} r+\pi_{t+h}^{*}+\beta\left(E_{t} \pi_{t+h}-\pi_{t+h}^{*}\right)+\zeta\left(e_{t}-e^{*}\right)$

where $E_{t} \pi_{t+h}$ is the forecast of inflation $h$ months in the future made in month $t$, and $\pi_{t+h}^{*}$ is the official inflation target $h$ months in the future. Under IT, the central bank responds positively to a deviation of the inflation forecast from the target. In line with the literature, a forecasting horizon of $h=12$ months is assumed. ${ }^{30}$ The term $e_{t}$ denotes the (log) forint-euro nominal exchange rate (an increase signals a depreciation), and $e^{*}$ represents the MNB's

${ }^{30}$ The 12-month horizon chosen here is within the range of the forecasting horizon of the MNB, described as between four and eight quarters in MNB (2002). Given the high serial correlation in 12-month inflation, the 12-month-ahead forecast is likely a good predictor of inflation at a longer horizon, and the results here are unlikely to be sensitive to small changes in the horizon assumed (such as 6 months). 
implicit exchange rate target. ${ }^{31} e^{*}$ may differ from the central parity rate. Finally, the $\overline{r r}$ term denotes the long-run equilibrium real interest rate.

76. An independent response to the exchange rate, after controlling for expected inflation, corresponds to a separate exchange rate objective. The literature identifies a number of possible reasons why a central bank may wish to respond to the exchange rate. In an open economy, movements in the exchange rate may carry important information about aggregate demand conditions that the central bank may wish to stabilize. Ball (2000) argues that monetary policy should react to exchange rate movements to offset the effects of the exchange rate on spending. Clarida, Galí, and Gertler (1998) find that in major industrialized countries the exchange rate played a role in setting monetary policy over the 1979-1994 period, but that its quantitative importance was small. ${ }^{32}$ However, having a separate exchange rate objective raises the possibility of a conflict between IT and the exchange rate regime.

77. In practice, central banks adjust policy rates gradually, so that the actual interest rate moves toward the desired policy rate. Reasons for wishing to adjust interest rates gradually in response to news include a possible loss of credibility following sudden policy reversals, as discussed in Clarida, Galí, and Gertler (1998). Accordingly, this process of gradual adjustment of the actual policy rate $i_{t}$ toward the desired level, $i_{t}^{*}$, is modeled following the literature as

$i_{t}=(1-\rho) i_{t}^{*}+\rho i_{t-1}+\varepsilon_{t}$,

where $\varepsilon_{t}$ denotes a mean-zero, serially uncorrelated policy shock. The empirical specification combines equations (6) and (7) from above and can be written as:

$i_{t}=(1-\rho)\left(\alpha+\pi_{t+12}^{*}+\beta\left(E_{t} \pi_{t+12}-\pi_{t+12}^{*}\right)+\zeta e_{t}\right)+\rho i_{t-1}+\varepsilon_{t}$,

where $\alpha$ is a constant that comprises (i) the natural rate of interest, $\overrightarrow{r r}$, and, (ii) the implicit exchange rate target, $\alpha=\overline{r r}-\zeta e^{*}$.

78. The model is estimated using IV to address the possible endogeneity of the inflation forecast and of the exchange rate to the interest rate in the current period.

\footnotetext{
${ }^{31}$ Given that the exchange rate band's central parity was altered from Ft 276 to Ft 282 per euro in June 2003, a structural break test is conducted for a change in the implicit inflation target at that date. However, the null hypothesis of no change in the implicit exchange rate target is not rejected by using a Chow breakpoint test.

${ }^{32}$ Similarly, Lubik and Schorfheide find that the Bank of Canada responds to exchange rate movements (Lubik and Schorfheide, 2003).
} 
The IV estimation is conducted following the two-stage-least squares procedure, using a standard set of instruments. The instruments are: six lags of policy rate, six lags of the inflation forecast, six lags of the log exchange rate, and a time trend.

\section{Data}

79. The sample of analysis is May 2001 to March 2005, that is, the period covering IT. The expected inflation term is measured using the Reuters survey of professional forecasters. Using actual inflation forecasts made in real time distinguishes this approach from much of the literature. The canonical approach is to measure expected inflation with actual future inflation. In addition, the explicit inflation targets for year's end can be interpolated to provide a continuous series of 12-month-ahead inflation targets, $\pi_{t}^{*}$. The nominal exchange rate, $e_{t}$, is calculated as the period average of the $(\log )$ forint-euro market rate. The nominal interest rate, $i_{t}$, is the official MNB policy interest rate. ${ }^{33}$

80. For robustness, the estimation is also conducted using an alternative, tax-adjusted measure of expected inflation. In early 2004, there was an increase in value-added and other indirect tax rates. The MNB announced that it would accommodate the first-round effects of the indirect tax shocks on prices (as described in the August 2003 Quarterly Report on Inflation). The estimated direct impact of changes in the taxes on the price level was estimated by MNB staff at 1 percent. $^{34}$ Accordingly, 1 percentage point is subtracted off the expected inflation rate for 2004.

81. Figure 6 suggests that the policy rate has responded positively to increases in the inflation forecast above target and to forint depreciations. The figure displays the policy rate along with the expected inflation gap and the exchange rate. The figure also suggests that the interest rate is more strongly correlated with the exchange rate than with the inflation gap, but formal analysis in the next subsection is required to test this hypothesis.

\section{Results}

82. Estimates of the policy reaction function for the IT period suggest that the MNB has responded to both expected inflation and the exchange rate. As reported in Table 3 , the response to the inflation gap is 1.48, in line with the IT responses of other central banks, as described, for instance in Clarida Galí, and Gertler (1998). The response is significant at

${ }^{33}$ Ideally, the inflation forecasts would be the MNB's own internal forecasts, published in the Quarterly Report on Inflation. However, since the start of IT, only 16 such reports have been published, limiting the number of observations to 16. For a detailed comparison of the Reuters and MNB inflation forecasts, see Chapter 4.4 of the February 2005 Quarterly Report on Inflation.

${ }^{34}$ See the August 2003 Quarterly Report on Inflation for details of how the first-round impact was estimated. 
the 10 percent level. However, when the tax-adjusted expected inflation measure is used, the inflation response is no longer statistically significant.

Figure 6. Hungary: Interest Rate, Expected Inflation Gap, and Exchange Rate, May 2001-March 2005

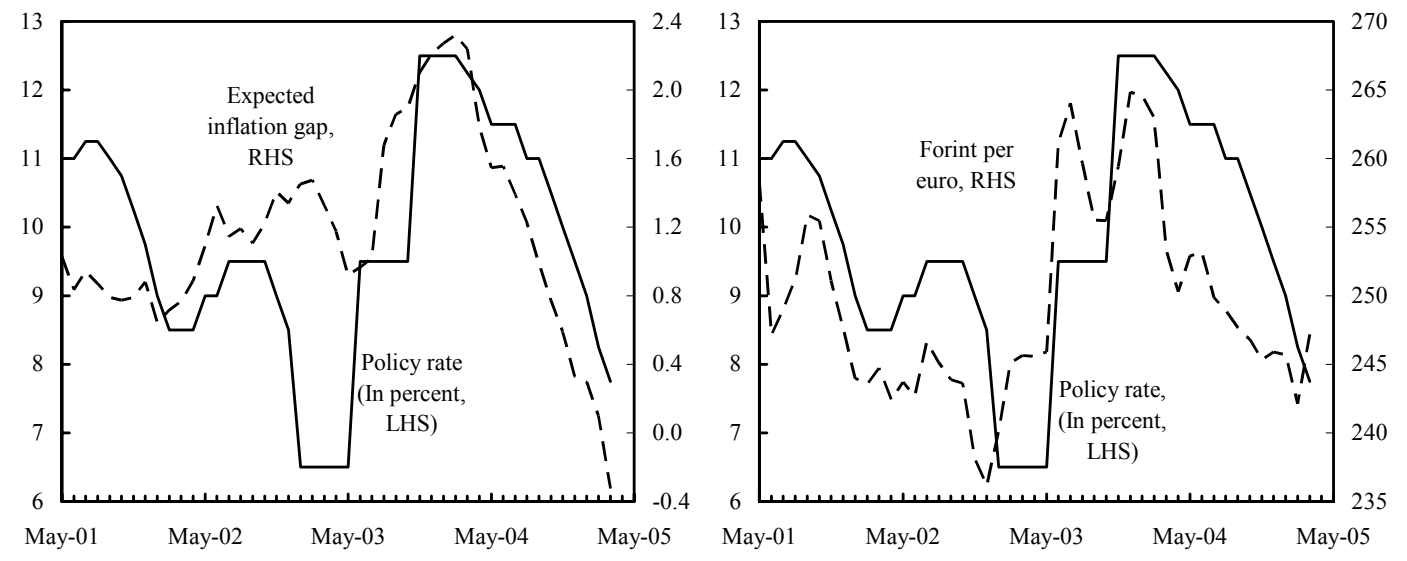

83. The response to the exchange rate is positive and significant at the 5 percent level, even after controlling for the inflation forecast. This result suggests that the MNB has, at times, responded to the exchange rate over and beyond the exchange rate's predictive power for future inflation. This finding is intuitive, given the policy commitment to keep the exchange rate within the band. When the tax-adjusted expected inflation measure is used, the exchange rate response rises in both magnitude and statistical significance. The estimate of $\rho=0.74$ provides evidence of interest rate inertia, in line with estimates for other central banks. Finally, the high $R^{2}$ indicates that the model fits the interest rate data well.

Table 3. Estimates of the MNB Monetary Policy Reaction /1

Estimates of equation: $i_{t}=(1-\rho)\left(\alpha+\pi_{t+12}^{*}+\beta\left(E_{t} \pi_{t+12}-\pi_{t+12}^{*}\right)+\zeta e_{t}\right)+\rho i_{t-1}+\varepsilon_{t}$

\begin{tabular}{ccccccc}
\hline \hline Expected & & & & & & Test \\
Inflation Measure & $\beta$ & $\zeta$ & $\rho$ & $\alpha$ & $R^{2}$ & $p$-value \\
\hline Total CPI & 1.48 & 0.52 & 0.75 & -2.86 & 0.87 & $\zeta=0$ \\
& $(0.85)$ & $(0.26)$ & $(0.08)$ & $(1.42)$ & & $(0.047)$ \\
Tax-adjusted CPI & 1.79 & 0.72 & 0.80 & -3.91 & 0.86 & $\zeta=0$ \\
& $(1.39)$ & $(0.26)$ & $(0.06)$ & $(1.42)$ & & $(0.008)$ \\
\hline \hline
\end{tabular}

1/ All standard errors are corrected for heteroscedasticity and serial correlation using a Newey-West procedure.

\section{A counterfactual simulation reveals that the policy rate would have been set} more smoothly without the independent exchange rate response. The policy rate based solely on the IT component of the reaction function in equation (9) is denoted by $i_{t}^{I T}$ : 
$i_{t}^{I T}=\bar{r} r+\pi_{t+12}^{*}+\beta\left(E_{t} \pi_{t+12}-\pi_{t+12}^{*}\right)$.

Based on the estimated reaction function for the total CPI, the inflation response parameter is set to $\beta=1.48$. The equilibrium interest rate is set to $\overline{r r}=4$ percent. In line with the

literature, this value is the mean of the exante real interest rate over the sample of analysis. ${ }^{35}$ Figure 7 compares the interest rate based on solely on IT with the actual interest rate over the 2001-05 period. In late 2002 and early 2003, inflation was expected to meet or slightly overshoot its target, but the exchange rate had approached the strong edge of the band. As Figure 7 suggests, the MNB responded by cutting rates by 300 basis points between October 2002 and January 2003, to below the level that could be justified based on IT considerations. This 300-basis-point cut was subsequently fully reversed in June 2003. Then, in November 2003, an additional 300-basis-point hike raised rates well above the level that could be justified by IT considerations alone. Once again, it appears that this response was motivated by exchange rate movements. Starting in March 2004, policy interest rates were lowered gradually. By early 2005, interest rates had reached the levels that would be expected based on IT considerations. Figure 7 shows that these conclusions are robust to conducting the counterfactual simulation with the tax-adjusted inflation series.

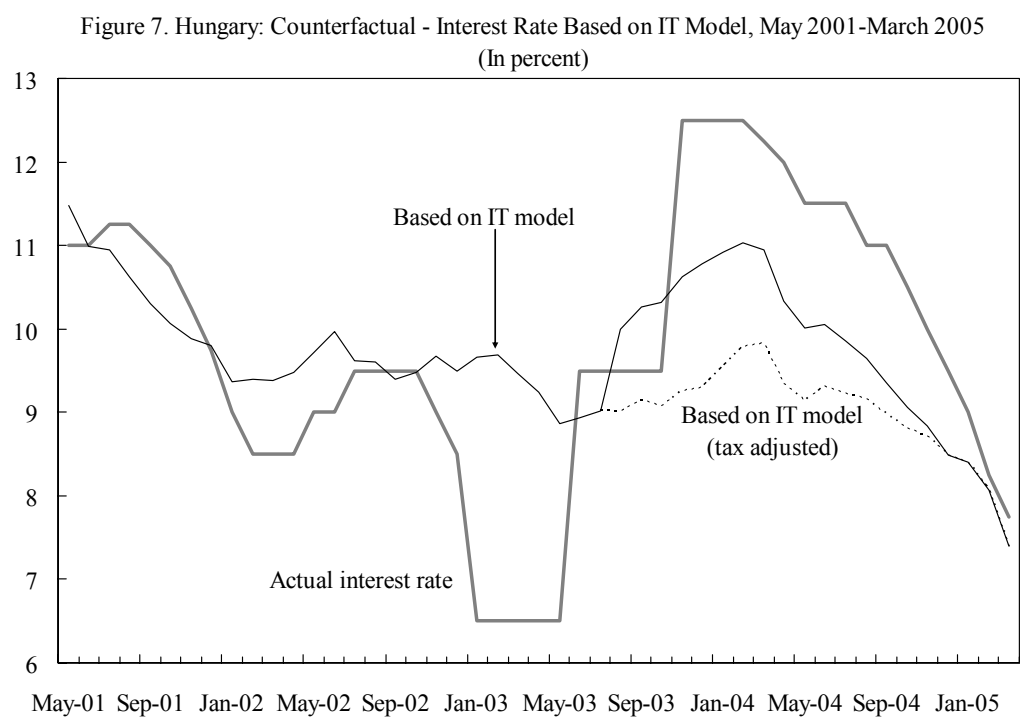

\section{Conclusions}

\section{This chapter has addressed two questions related to recent inflation}

developments in Hungary. First, how persistent has inflation been? Second, what factors have influenced the setting of policy interest rates since the introduction of IT in 2001 ?

${ }^{35}$ A series for the exante real interest rate was obtained from the MNB Quarterly Report on Inflation of February 2005. 
86. The main findings are as follows. First, the analysis reveals a significant forward-looking component in Hungarian inflation, implying that inflation persistence is relatively low. This finding, in part, helps to explain why Hungarian inflation declined rapidly following the 2004 inflation shocks. Second, while monetary policy decisions have appropriately responded to the inflation forecast, exchange rate-stabilizing considerations have also played a role that has not always been consistent with the objective of directly lowering the rate of inflation. 


\section{REFERENCES}

Ball, Laurence, 1995, “Disinflation With Imperfect Credibility,” Journal of Monetary Economics, Vol. 35, February, pp. 5-23.

, 2000, “Policy Rules and External Shocks,” NBER Working Paper No. 7910

(Cambridge, Massachusetts, National Bureau of Economic Research).

Buiter, W.H. and C. Grafe, 2001, "No Pain, No Gain? The Simple Analytics of Efficient Disinflation in Open Economies," CEPR Discussion Paper No. 3038 (London: Center for Economic Policy Research).

Calvo, Guillermo, 1983, "Staggered Prices in a Utility Maximizing Framework," Journal of Monetary Economics, Vol. 12, (No. 3), pp. 383-98.

Carroll, Christopher D., 2003, "Macroeconomic Expectations of Household and Professional Forecasters," Quarterly Journal of Economics, Vol. 118, Number 1, (February), pp. 269-98.

Celasun, Oya, R. Gaston Gelos, and Alessandro Prati, 2003, "Would 'Cold Turkey' Work in Turkey?” IMF Working Paper 03/49 (Washington: International Monetary Fund).

,2004, "Obstacles to Disinflation: What is the Role of Fiscal Expectations?" Economic Policy, No. 40 (October), pp. 441-81.

Clarida, Richard, Jordi Galí, and Mark Gertler, "Monetary Policy Rules in Practice: Some International Evidence,” European Economic Review, Vol. 42 (June) pp. 1033-67.

Cogley, Timothy, and Thomas J. Sargent, 2001, "Evolving Post-World War II U.S. Inflation Dynamics," in NBER Macroeconomics Annual 2001, ed. by Ben Bernanke and Kenneth Rogoff (Cambridge, Massachusetts: MIT Press), pp. 331-73.

Fuhrer, Jeffrey C., and George R. Moore, 1995, "Inflation Persistence," Quarterly Journal of Economics, Vol. 110 (February) pp.127-59.

Galí, Jordi, and Mark Gertler, 1999, "Inflation Dynamics: A Structural Econometric Analysis," Journal of Monetary Economics, Vol. 44 (October), pp. 195-222.

Kiss, Gergely, and Judit Krekó, 2004, “The Optimal Rate of Inflation in Hungary,” MNB Background Studies 1/2004 (Budapest: Magyar Nemzeti Bank).

Krekó, Judit, and Balázs Vonnák, 2003, “Makroelemzök Inflációs Várakozásai,” MNB Háttértanulmányok 2003/1 (Budapest: Magyar Nemzeti Bank). 
Lubik, Thomas, and Frank Schorfheide, 2003, "Do Central Banks Respond to Exchange Rate Movements? A Structural Investigation" (unpublished; Baltimore and Philadelphia: Johns Hopkins University and University of Pennsylvania).

Magyar Nemzeti Bank, 2002, Monetary Policy in Hungary (Budapest: Magyar Nemzeti Bank). , 2001, Press Release, June 12. , Quarterly Report on Inflation, several issues.

Rogoff, Kenneth, 2003, “Globalization and Global Disinflation," in Monetary Policy and Uncertainty: Adapting to a Changing Economy (Kansas City, Missouri: Federal Reserve Bank of Kansas City).

Stock, James H., 2001, “Comment on 'Evolving Post-World War II Inflation Dynamics,"” in NBER Macroeconomics Annual 2001, ed. by Ben Bernanke and Kenneth Rogoff (Cambridge, Massachusetts: MIT Press), pp. 379-87. 